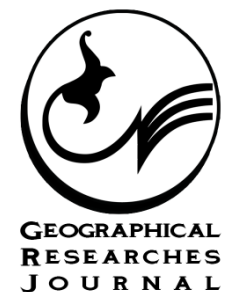

\title{
Role of Quaternary Tectonic and Climatic Factors on the Geomorphological Changes of Meshkin Shahr Depression Alluvial Fans
}

\section{ART I CLE IN F O}

\section{Article Type}

Original Research

\section{Authors}

Nouhi M. ${ }^{1} M A$,

Madadi A. ${ }^{* 1} P h D$,

Abedini M. ${ }^{1} P h D$

\section{How to cite this article}

Nouhi M, Madadi A, Abedini M. Role of Quaternary Tectonic and Climatic Factors on the Geomorphological Changes of Meshkin Shahr Depression Alluvial Fans. Geographical Researches Quarterly Journal. 2019;34(2):281 -292 .

${ }^{1}$ Department of Geography, Faculty of Literature \& Humanities, Mohaghegh Ardabili University, Ardabil, Iran

\section{*Correspondence}

Address: Department of Geography, Faculty of Literature \& Humanities, Mohaghegh Ardabili University, Daneshgah Street, Ardabil, Iran Phone: +98 (45) 31505659 Fax: +98 (45) 31505510 aghil48madadi@yahoo.com

\section{Article History}

Received: January 30, 2018

Accepted: May 4, 2019

ePublished: June 20, 2019

\section{A B S T R A C T}

Aims \& Backgrounds Based on field and literature studies, one of the most important features of Sabalan Quaternary landscape, are climate changes and tectonic activities. So tectonic activities and climate changes, along with other internal and external factors simultaneously had an undeniable role in the formation and evolution of Quaternary fans of Meshkin Shahr depression. The purpose of this study was to investigate the role of tectonic and climatic factors of quaternary period in geomorphological evolution of Meshkin Shahr fans.

Methodology To achieve this goal, first of all, using contour line, stream network and elevation points, the digital elevation model of region, was prepared as a base map. Then the data needed to calculate geomorphic indices and various profiles were extracted. Geological logs are used to investigate sedimentary evidence. In addition, Arc hydro and Google earth have been used to outline catchments and fans area. In addition, to draw geological logs, Rock works 16 software was used. Most importantly, we have used extensively field observations.

Findings The two major phenomena of volcanic-tectonic and climate changes in the Quaternary period have played a decisive role in the formation and development of the Quaternary fans of Meshkin Shahr depression. Simultaneously, the Sabalan volcanic activity with glacial dominate or tundra storm during the late Pleistocene led to the formation of a mudflow periodically and sedimentation in fans and basins. In contrast, climate change from glacial period to interglacial during the Holocene and tectonic relaxation has caused the incision of basins and fans.

Conclusion Sabalan's landscape as the main controller of Meshkin Shahr Depression Fans is at a transitional stage, which means that it has undergone a tectonic stage to a non-tectonic stage, and also, it has undergone a glacial to an interglacial period such as the present conditions.

Keywords Geomorphic Indices; Sabalan Mountain; Tectonics; Climate; Alluvial Fans

\section{I T A T I O N L I N K S}

[Blair \& McPherson; 2009] Processes and forms of alluvial ...; [Bull; 1972] Recognition of alluvial fan deposits in the stratigraphic ...; [Bull; 2008] Tectonic geomorphology of mountains: A new ...; [Bull; 2011] Tectonically active ...; [Burbank \& Anderson; 2013] Tectonic ...; [Chen, et al; 2006] Variations in tectonic activities of the central and southwestern Foothills, Taiwan, inferred ...; [Demoulin; 1998] Testing the tectonic significance of some parameters of longitudinal river profiles: The case of ...; [Harvey, et al; 2005] Alluvial fans: Geomorphology, sedimentology, dynamics ...; [Hooke; 1965] Alluvial ...; [Kumar, et al; 2007] Evolution of the quaternary alluvial fan system in the Himalayan foreland ...; [Pérez-Peña, et al; 2010] Active tectonics in the Sierra Nevada ...; [Quigley, et al; 2007] Distinguishing tectonic from climatic controls on range-front ...; [Viseras, et al; 2003] Differential features of alluvial fans controlled by ...; [Whittaker; 2012] How do landscapes record tectonics and ...; [Zaprowski, et al; 2005] Climatic influences on profile concavity and river ...; [Amini; 1994] Geological map of Meshkinshahr, Scale, 1: 100000, Sheet ...; [Babakhani \& Khanazareh; 1991] Geological map of Lahrood, Scale, 1: 100000, Sheet ...; [Dallal Oghli;2003] The study of the effective morphogenesis systems in the northern ...; [Darvish Zade; 2007] Volcanology; [Goorabi \& Karimi; 2012] The effect of active tectonics and climate change ...; [Kamali, et al; 2018] Investigation of Drood fault (Southwestern Iran) based on geological ...; [Khayyam; 1993] An attempt on the constructional and volcanic morphology of the Azerbaijani ...; [Khayyam \& Mokhtari; 2003] Evaluation of the role of tectonic activities ...; [Maghsoudi; 2008] Investigating the factors affecting the development of the fans ...; [Motamed; 1994] Geography ...; [Mousavi, et al; 2011] Discussion on stratigraphy questions at Sabalan ...; [Rajabi \& Bayati Khatibi; 2012] The geomorphology of northwest ...; [Rajabi \& Soleimani; 2013] Analysis and evaluation of the morphotectonic and neotectonic ...; [Rustai, et al; 2009] The role of tectonic activities in the formation and development of alluvial fans in the southern slopes of Ala ...; [Sahabi; 1999] Sabalan volcanic complex with special reference to the hydrotermal ...; [Sharifi Najafabadi; 2019] Glacial and tectonic evidence of late Quaternary in ...; [Taghian; 2016] Investigating the role of tectonic on the morphology...; [Yamani \& Maghsoudi; 2003] The role of tectonics and climate change on the development of ... 
تكتونيك و اقليم به صورت همزمان و همراه هم در تحول

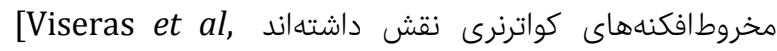
[2003. قراركيرى كوهستان آتشفشانى يليو-كواترنر سبلان بان

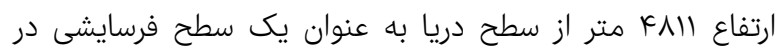

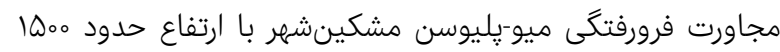

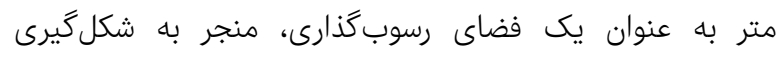

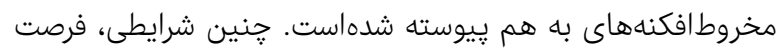

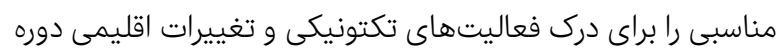

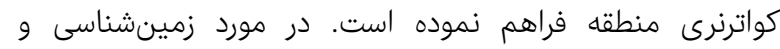

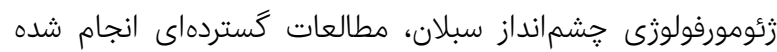

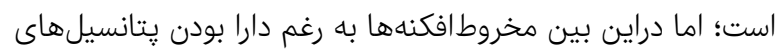

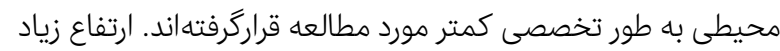

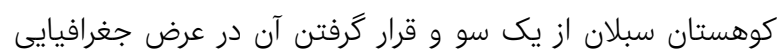

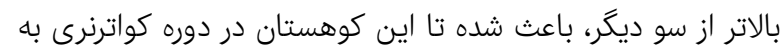

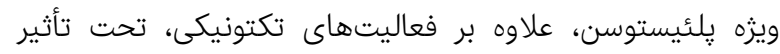

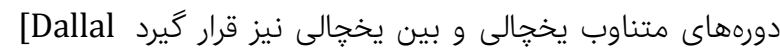
oghli, 2003; Khayyam, 1993; Rajabi \& Khatibi, [2012. براساس مطالعات ميدانى و كتابخانهاي، آثار اين فرايندها

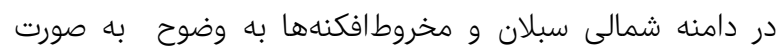

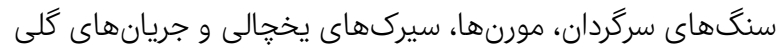

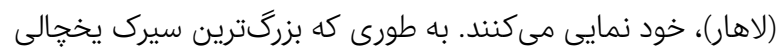

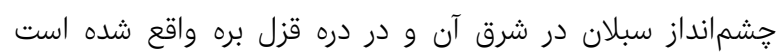
[Rajabi \& Khatibi, 2012]

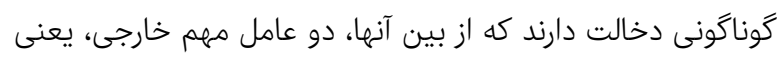

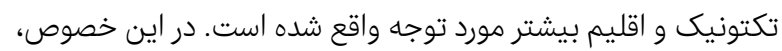

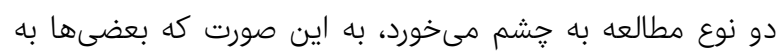

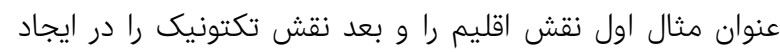

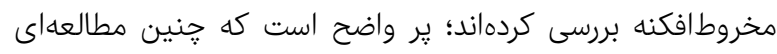

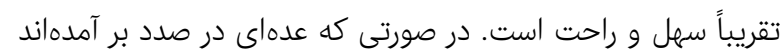

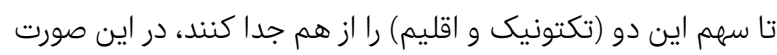

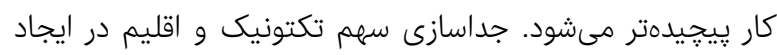

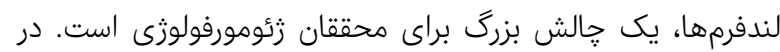

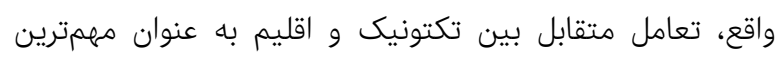

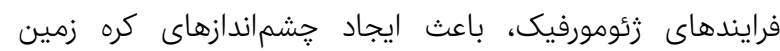

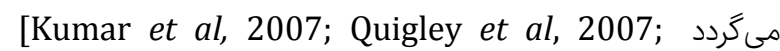

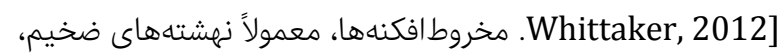

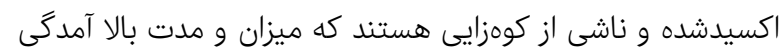

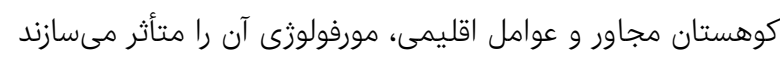

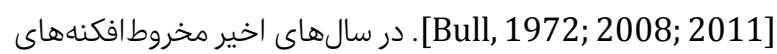

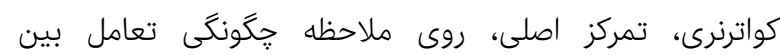

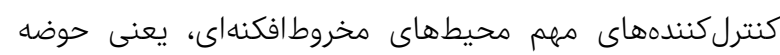
آبريز، تكتونيك، تحول زئومورفيك، اقليم و سطح اساس بكاي بوده است

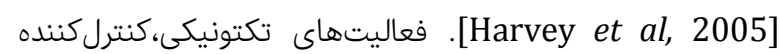
تأمين رسوب در بلندمدت هستند؛ اما الكوهاى زمانى و فضايى

\section{نقش عوامل تكتونيكى و اقليمى دوره كواترنرى در تحول زئومورفولوزيك مخروطافكنههاى فرورفتكى ندئي مشكينشهر}

MA محمد نوحى كروه جغرافيا، دانشكده ادبيات و علوم انسانى، دانشًاه محقق اردبيلى، اردبيل، ايران عhD عقيل مددى جعريا، گروه جغرافيا، دانشكده ادبيات و علوم انسانى، دانشگاه محقق اردبيلى، اردبيل، ايران

Pوسى عابدينى ShD گروه جغرافيا، دانشكده ادبيات و علوم انسانى، دانشعاه محقق اردبيلى، اردبيل، ايران

جكيده اهداف و زمينهها: با توجه باه مطالعات ميدانى و كتابخانهاى، يكى از ويزگىهاى

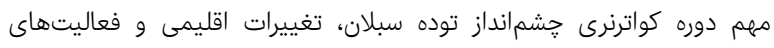

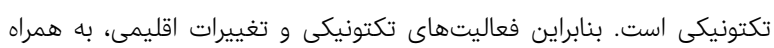

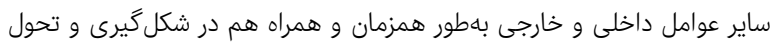

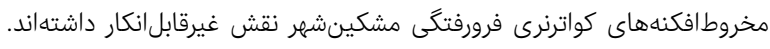

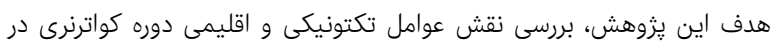

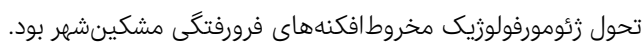

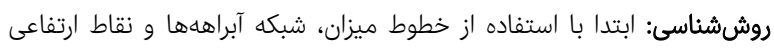

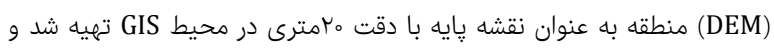

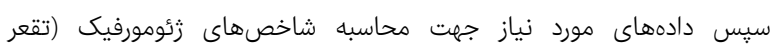
رودخانهها، يروفيل نيمه لعاريتمى رودخانهها و برش رأس مخروطاز افكنهها)، رسم

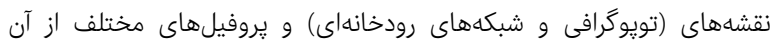

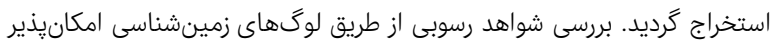

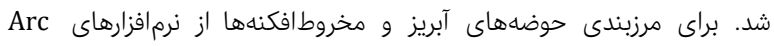

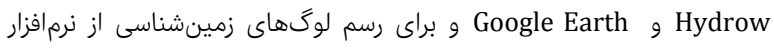

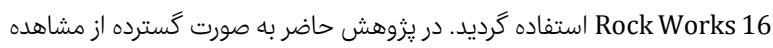
ميدانى استفاده شد.

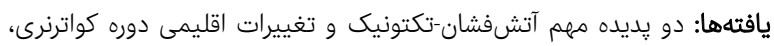

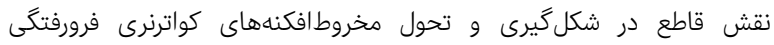

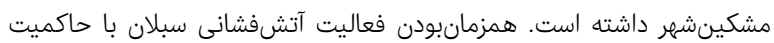

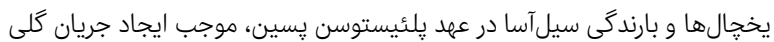

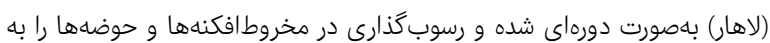

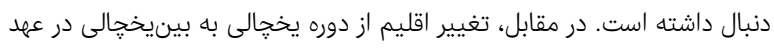

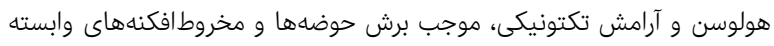
شده است.

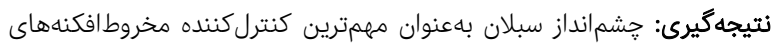

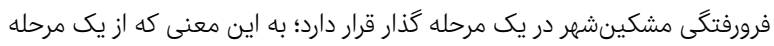

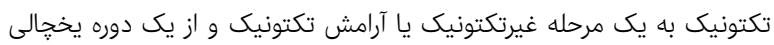

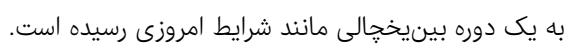
كليدواثهها: شاخصهاى ثئومورفيك، قله سبلان، تكتونيك، اقليم، مخروطانئ افكنه

تاريخ دريافت: تاريخ تاريخ קذيرش: تاريخ درياف: و ثويسنده مسئول: بونيخ: aghil48madadi@yahoo.com

مقدمه دوره كواترنرى به عنوان تناوبى از دورههاى يخجالى و بين يخجالى،

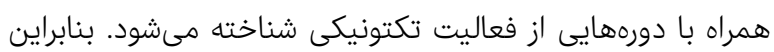


نقش عوامل تكتونيكى و اقليمى دوره كواترنرى در تحول زئومورفولوريك مخروطافكنهاى فرورفتكى مشكينشهر سرب

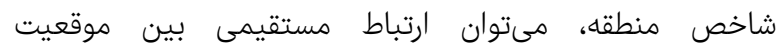

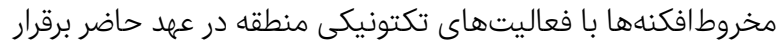

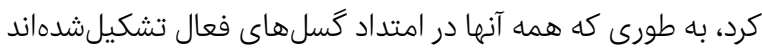
و اثرات اين فعاليت را مىتوان با جابهجايى راست بر آبراهيه

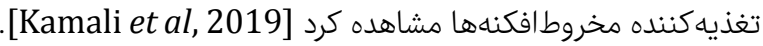
براى انجام اين كار از شاخصهاى زئومورفيك حوضهاى مخروطافكنهاى و نيز شواهد رسوبى استفاده شده است. تأكيد ما در انجام اين يزوهش بيشتر روى مطالعات ميدانى بوده است.

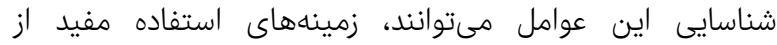

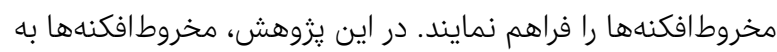

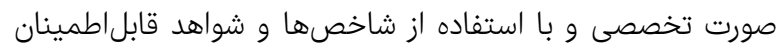

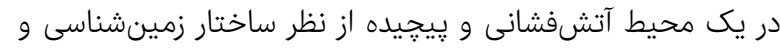

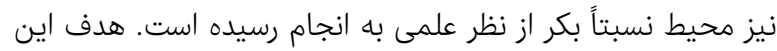

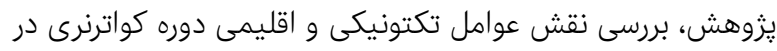

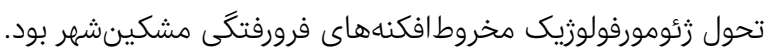

\section{روششناسى}

ابتدا با استفاده از خطوط ميزان، شبكه آبراههها و نقاط ارتفاعى

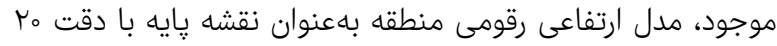

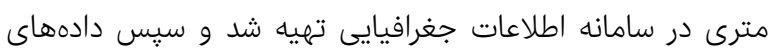

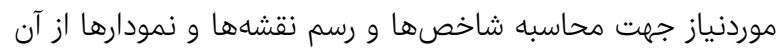

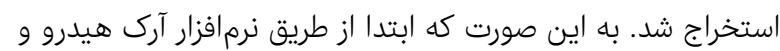

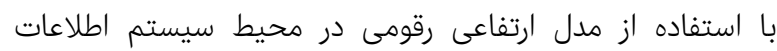

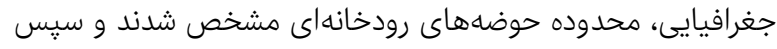

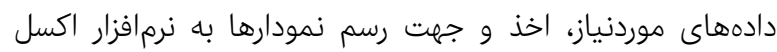

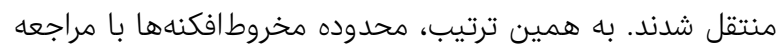

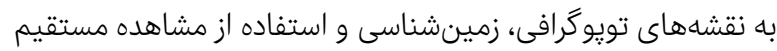

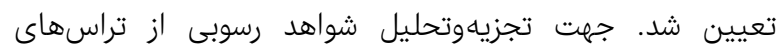

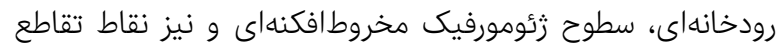

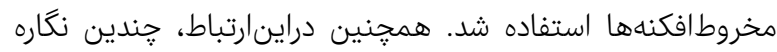

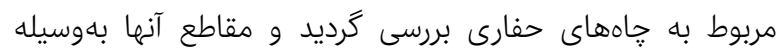

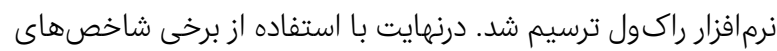

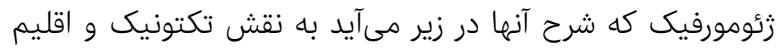

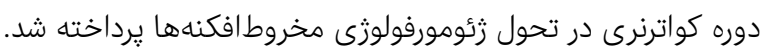

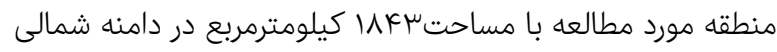

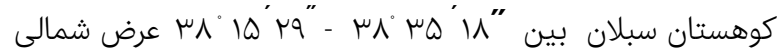

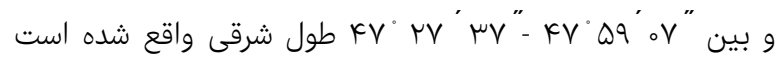

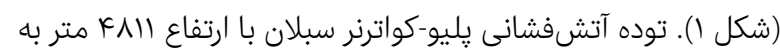
عنوان يكى از واحدهاى مورفوتكتونيك شمال غربى كشور Rajabi] [ Soleimani, 2013 در بخش جنوبى منطقه قرار دارد و نقش ونش

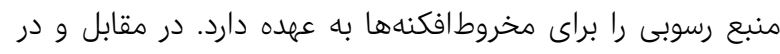

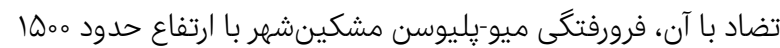

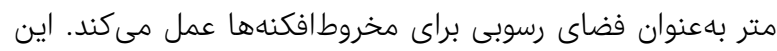

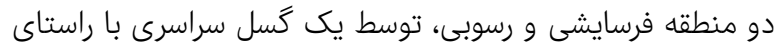

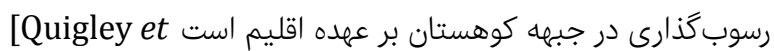

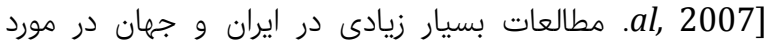
مخروطافكنهها صورت گرفته است، به طورى كه امروزه در بعضى از از

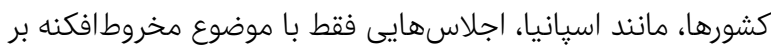

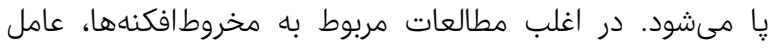

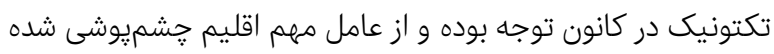

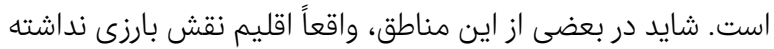

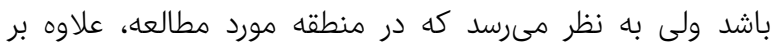

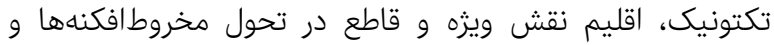

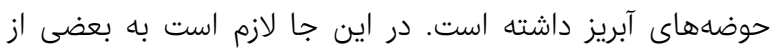

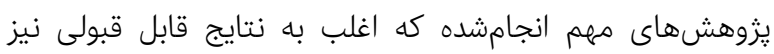

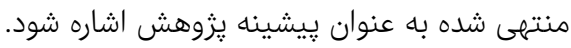
يمانى و مقصودى [Yamani \& Magsoudi, 2003] در بررسى و و تحول كانالهاى گيسويى در سطح مخروطافكنههاى إنهاله سيرجان به اين نتيجه رسيدند كه در تحول و تكامل مخروطافكنهها، حركات

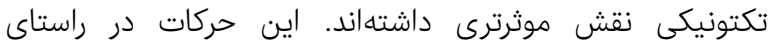

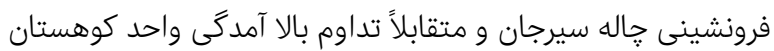

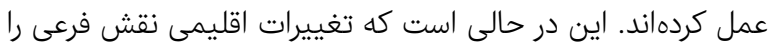
بر عهده داشته است. در تحقيقى ديكر، كورابى وكريمى Goorabi

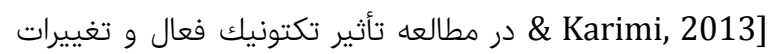
اقليمى در تحول مخروطافكنه مروست، ايران مركزى، دريافتند كه

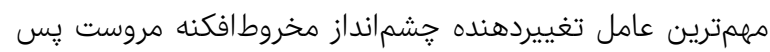

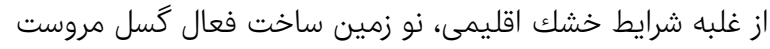

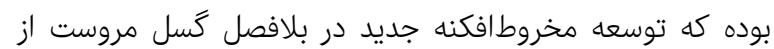

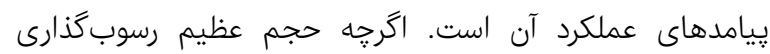

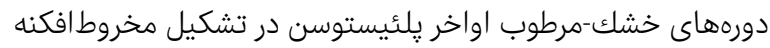

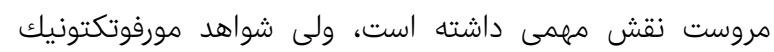

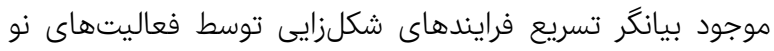

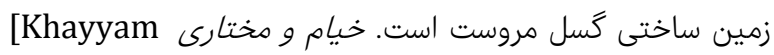

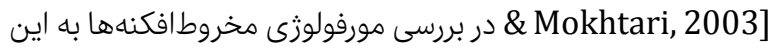

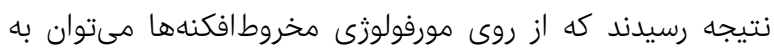

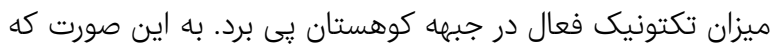

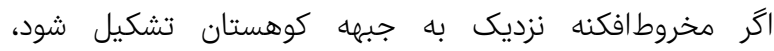
نشاندهنده تكتونيك فعال و اگر دور از جبهه كوهستان و در قاعده مخروطافكنه قديمى تشكيل شود، حاكى از تكتونيك غيرفعال يا كم

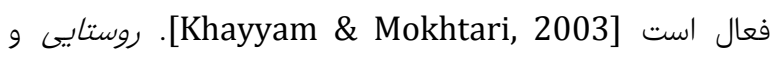
همكاران [Rustai et al, 2010] در بررسى نقش فعاليتهاى تكتونيكى در شكل

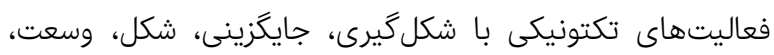

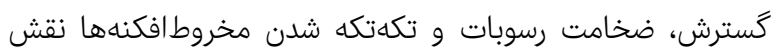
مهمى در تكامل مخروطافكنههاى دامنه جنوبى آلاداغ داشته است.

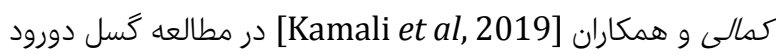
براساس شاخصهاى زئومورفيك مخروطافكنهاى به اين نتيجا ليه

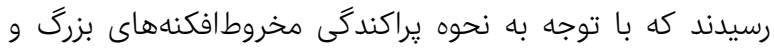


سبلان از نوع آتشفشان نقطهاى و مخروط آن از نوع مختلط است

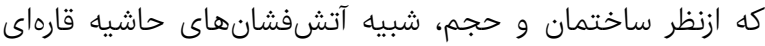
است، ولى ازنظر تركيب شيميايى شباهتى با انواع حاشيهاى ندارئ آندارد.

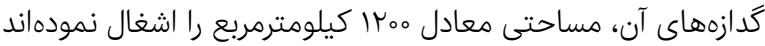

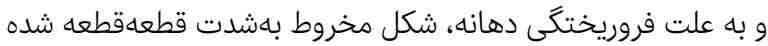

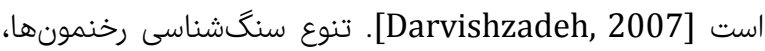
مربوط به تشكيل واحدهاى سنكى در فازهاى مختلف آتشفشانى رخائ

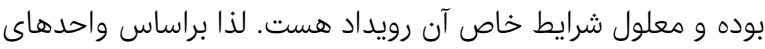

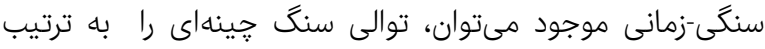

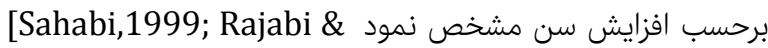

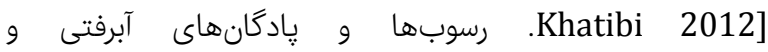

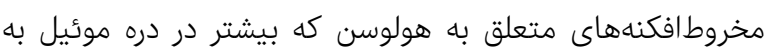

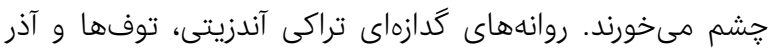
آورى يليوسن كه قبل از تشكيل دهانه است كه قاعده و قسمت رونت

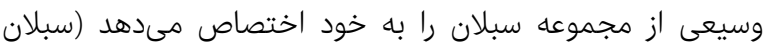

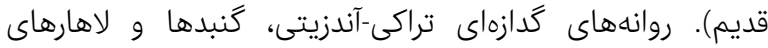
يلئيستوسن يايانى كه مربوط به بعد از تشكيل دهانه هستند (سبلان إندان جديد). در آخرين مرحله قلههاى مهرم سبلان هرئ جديد، مانند سلطان

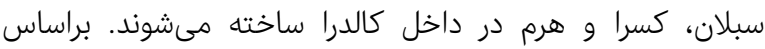

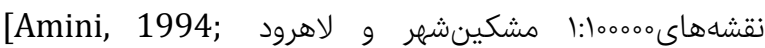

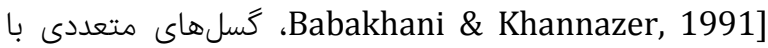

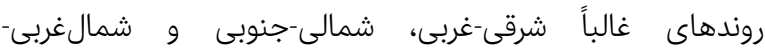

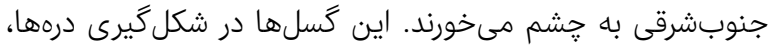

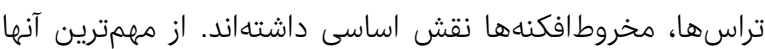
مىتوان به گسل كالدرا ، شيروان دره، قوتورسويى و موئيل اشاره

كرد. - م
شرقى- غربى از هم جدا مى همان هوند [Amini, 1994]. ازنظر اقليمى، كوهستان سبلان داراى آبوهواى سرد و خشى آشى كوهستانى و

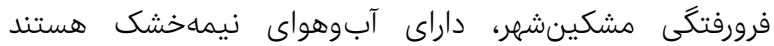

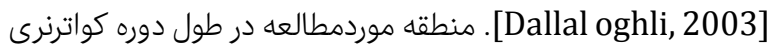
بهتناوب، تحت تأثير دورههاى يخجالى و بين يخجالى قرار داشته

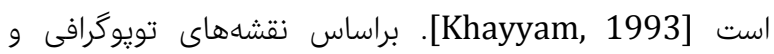
مطالعات ميدانى، جهار رودخانه خياو، كركرى، شيروان دره و اونار

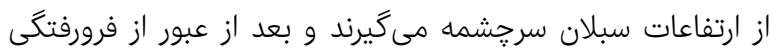
مشكينشهر وارد رودخانه قرهسو مىشوند. رودخانه قرهسو بهعنوان

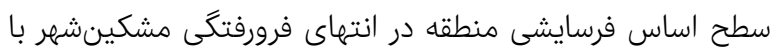

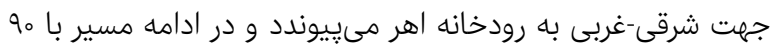

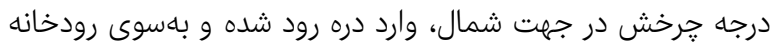
ارس حركت مىكند و بعد از ييوستن به رودخانه ارس به درياى خرد

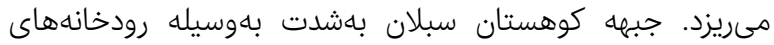
مذكور كه در جهت عمود بر جبهه كوهستان جريان دارند، بريدهشده

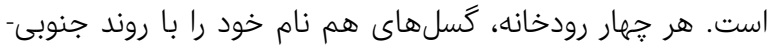

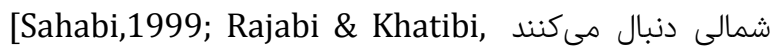
[2012. حاصل رقابت بىامان بين عوامل تكتونيكى كه تويوگرافى دئن

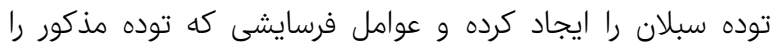
تخريب كرده، مخروطافكنههاى به همييوسته است كه تمام اين اين فعلوانفعالات را در خود ثبت كرده است. از قلههاى معروف منطقة هرده مىتوان به سلطان سبلان، هرم و كسرا اشاره كرد. طى دوره كواترنر،

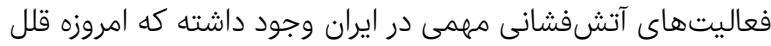
آنها ارتفاعات مهمى را تشكيل دادهاند. براساس دادههاى موجود،

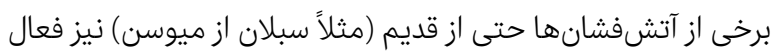

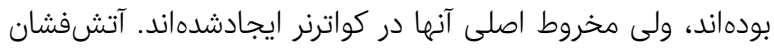

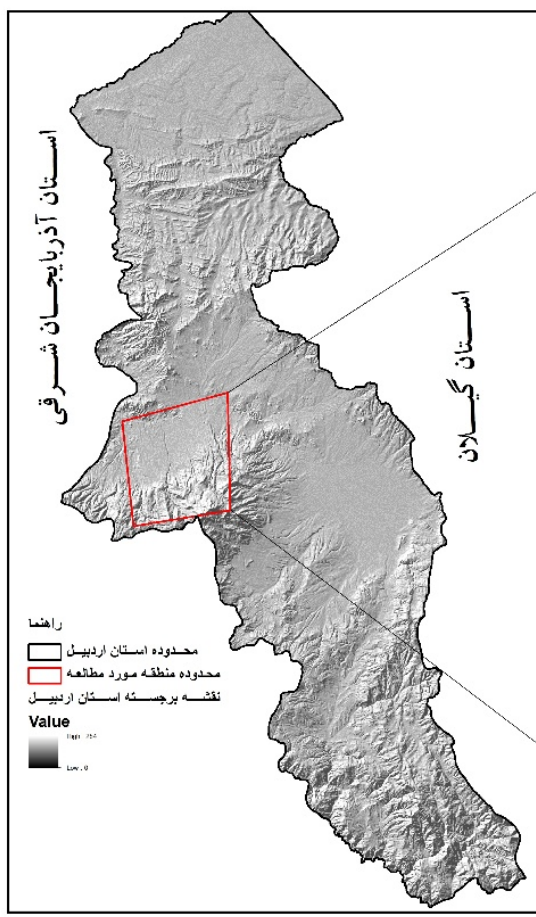

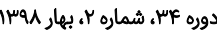

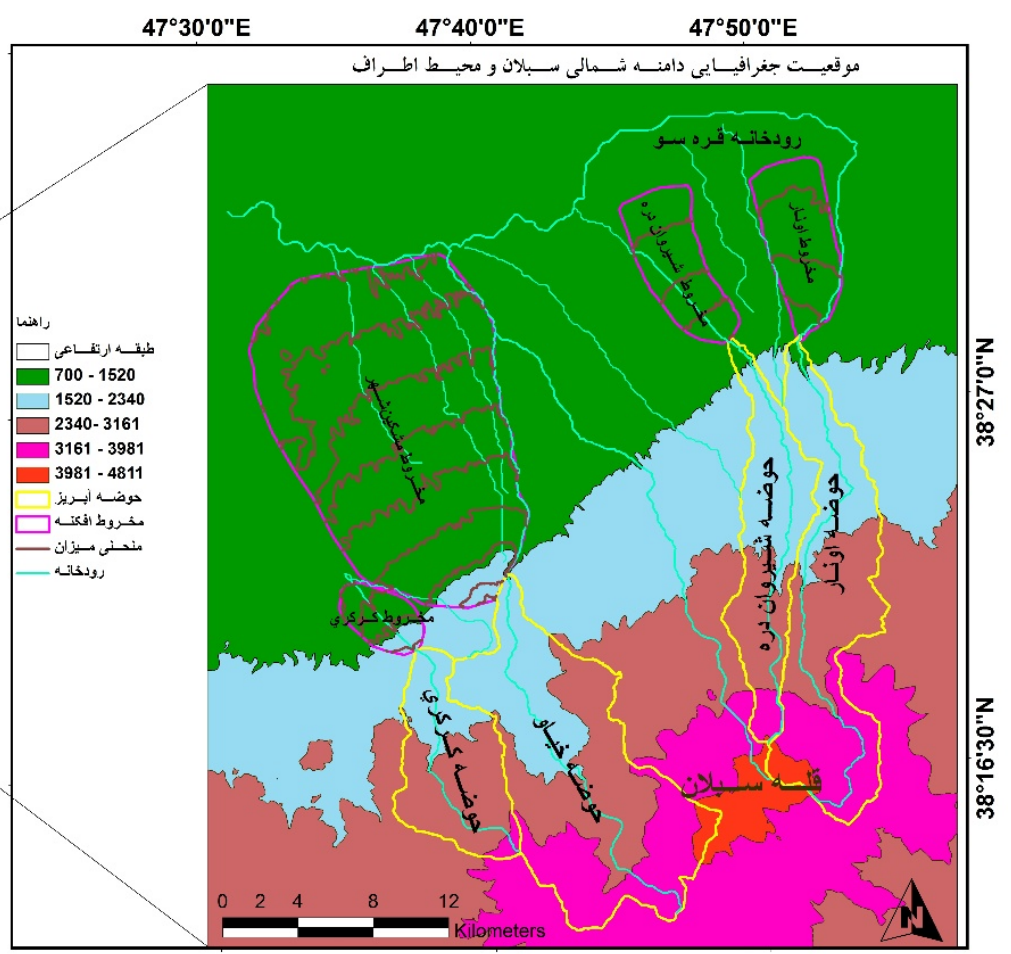

شكل () موقعيت جغرافيايى دامنه شمالى سبلان و فرورفتكى مشكينشهر 


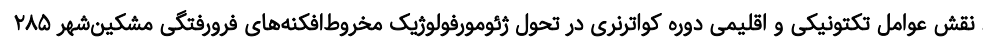

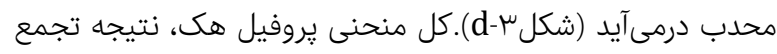
تأثير نيروهاى تكتونيكى در بلندمدت است. خط مستقيم بين منبع

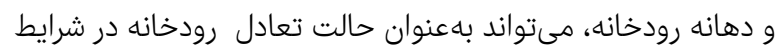
تعادل ديناميك باشد. شيب اين خط، گراديان درجهبندىشده (تعادل) K ناميده مىشود كه نماينده قدرت رودخانه محسوب

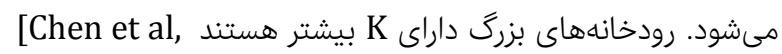
[2006. شاخص برش رأس مخروطافكنه: اين شاخص، يكى از مهمترين شاخصهاى زئومورفيك در بررسى نقش عوامل تكتونيكى و اقليمى در تحول مخروطافكنهها است. هنگامى كه نرخ فرايش در جبهه كوهستان بيشتر از نرخ فرسايش باشد، مخروطافكنه جديد در رأس مخروط افكنه قديمى و درواقع در محل جبهه كوهستان تشكيل مى گردد. اما هنگامى كه نرخ فرايش در جبهها كوهستان كمتر و يا

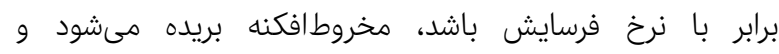

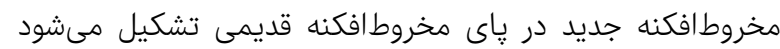

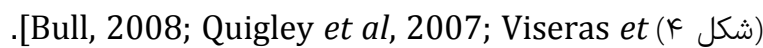

al, 2003]

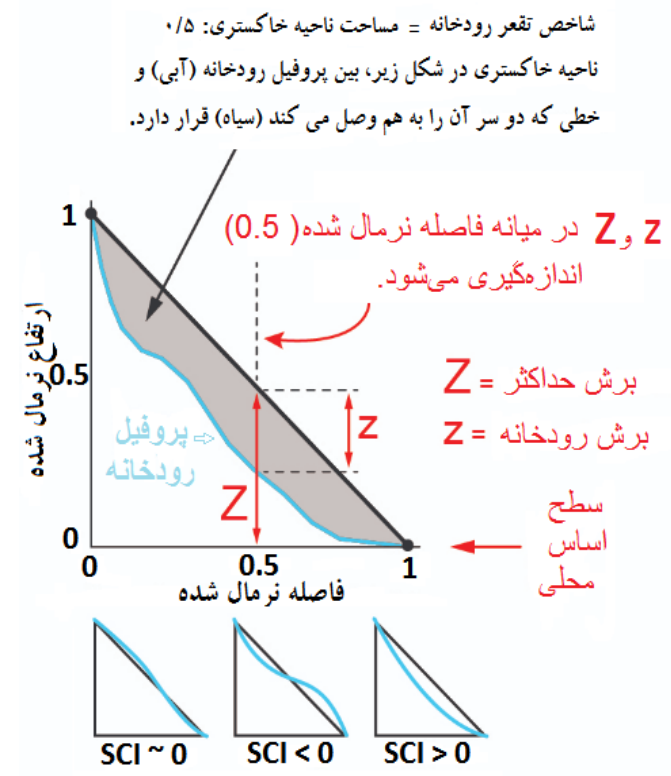

شكل r) روش محاسبه شاخص تقعر رودخانهها [Zaprowski et al, 2005]

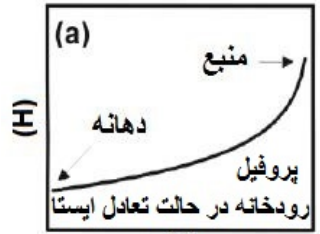

(L)

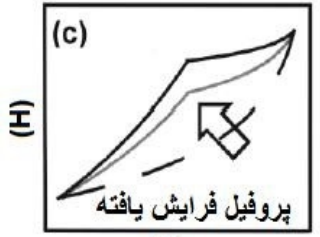

(L)

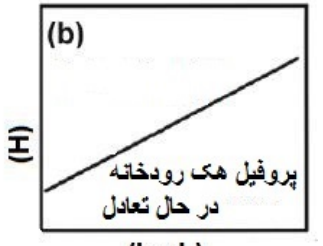

(logL)

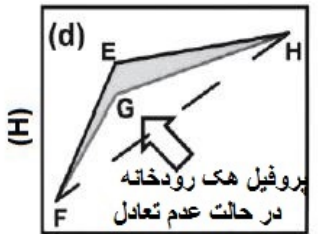

(logL)

شكل س) نمودار مفهومى يروفيل هك [Chen et al, 2006]

در اين بخش، شاخصها و شواهد زئومورفيك بهمنظور رديابى نقش تافت

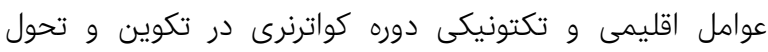

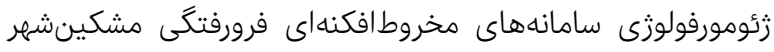

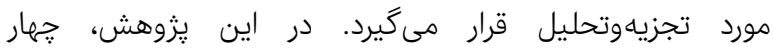

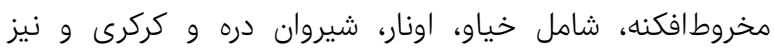

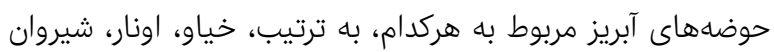

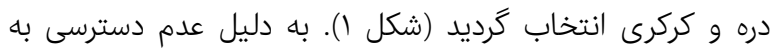

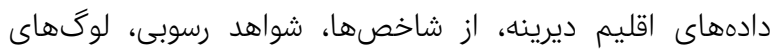

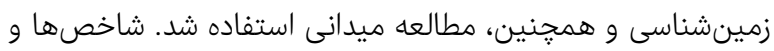

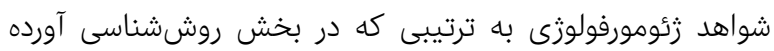
شده، موردبحث قرار مى تيردا.

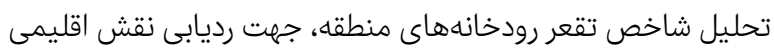

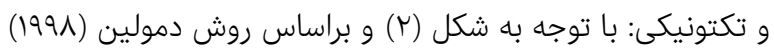

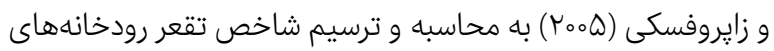

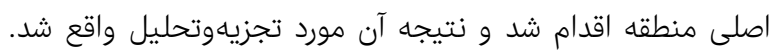

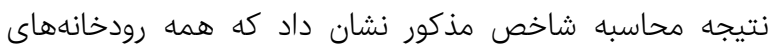
منطقه با مقدارهاى متفاوتى داراى تقعر مثبت هستند (Sci>0).

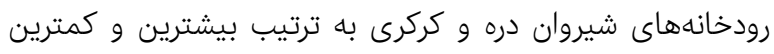

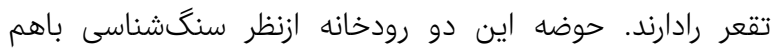

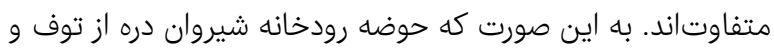

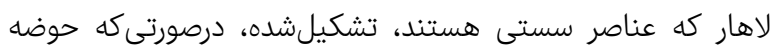

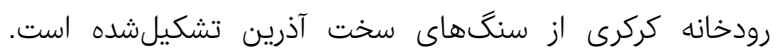
بهطوركلى اين مورفولوزى (تقعر) ناشى از تأثير فعاليت فرايندهاي

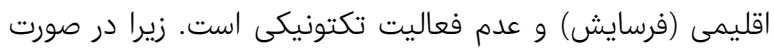

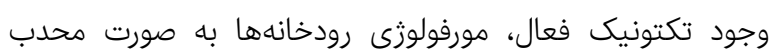

مى شد.

شاخص تقعر رودخانه از طريق رابطه بين ارتفاع نرمال شده و فاصله

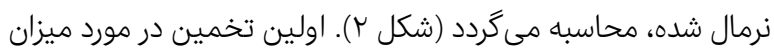

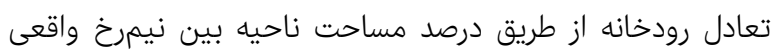

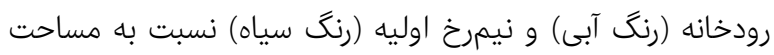

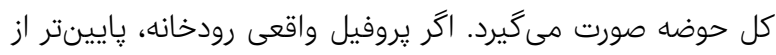

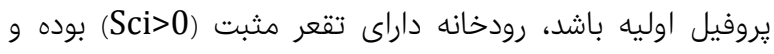

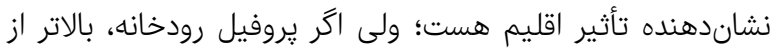
يروفيل اوليه باشد، رودخانه داراى تقعر منفى (Sci<0) بوده و وحاكى التى

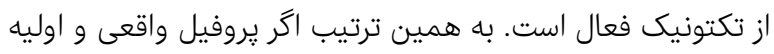
رودخانه روىهم منطبق شوند، نشاندهنده تقعر تقريباً ترنياً صفر [Demoulin, 1998; Zaprowski et al, اسنتان (Sci 0) .2005]

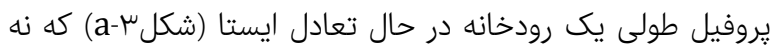

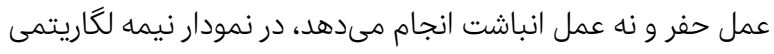

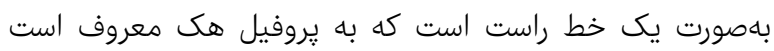

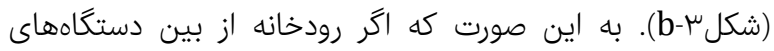

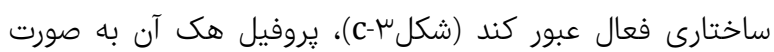




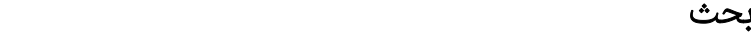
براساس مطالعات ميدانى و كتابخانهاى، در دوره يخجالى (دوره

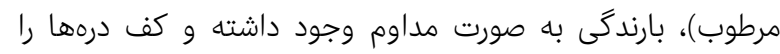

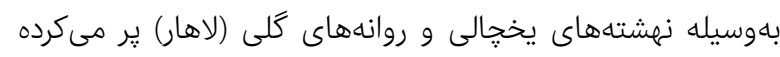
است. در دوره بين يخجالى (دوره نيمهخشك)، شرايطى مشابه امروز

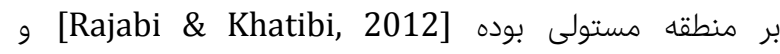
رودخانههاى سيلابى به حفر نهشتهای رواى سست و نرم يرداخته و تقعر رودخانهها را افزايش دادهاند (شكله).
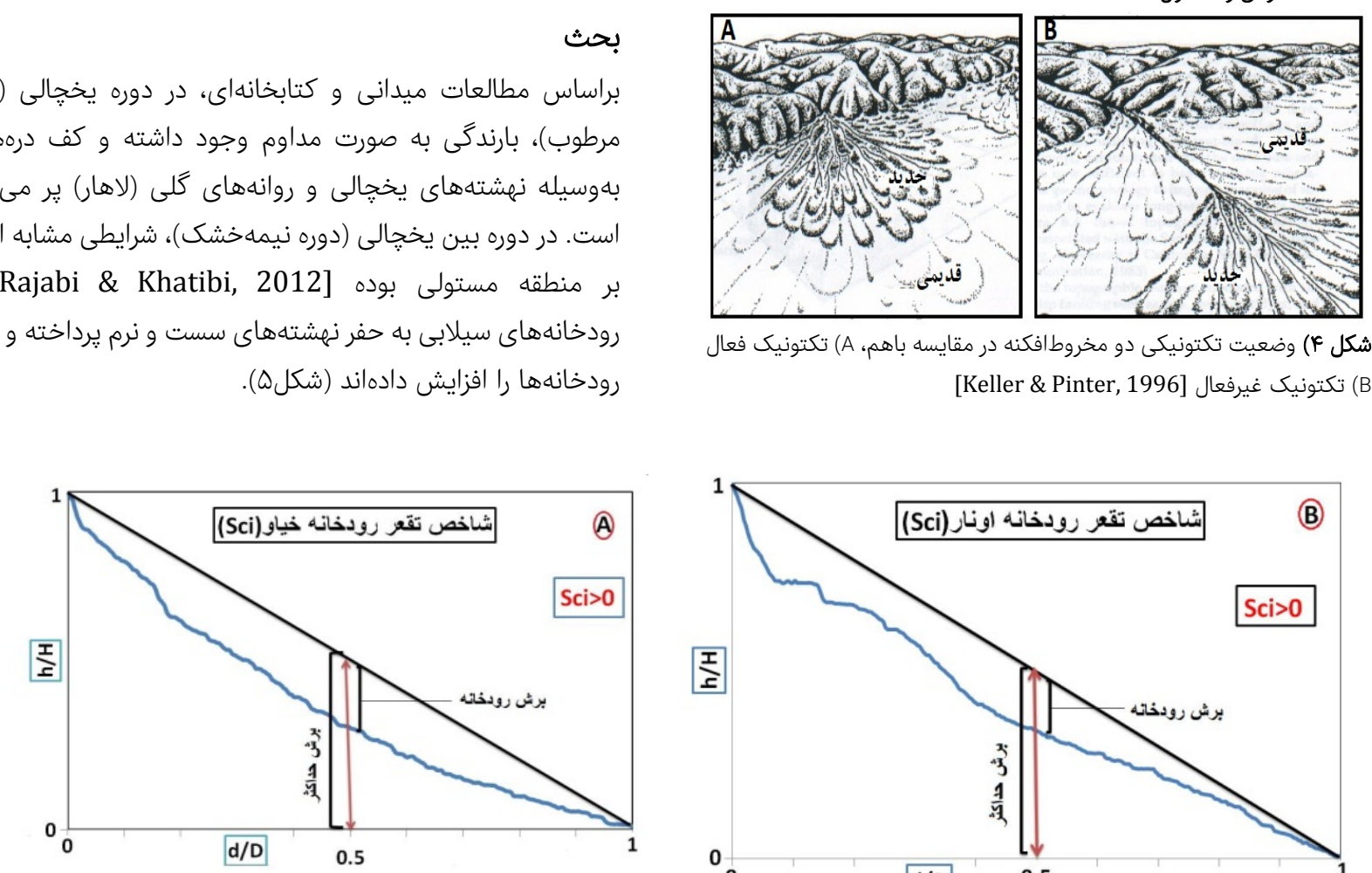

شكل F) وضعيت تكتونيكى دو مخروطافكنه در مقايسه باهم، A (A) تكتونيك فعال

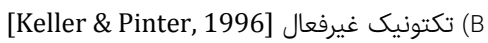
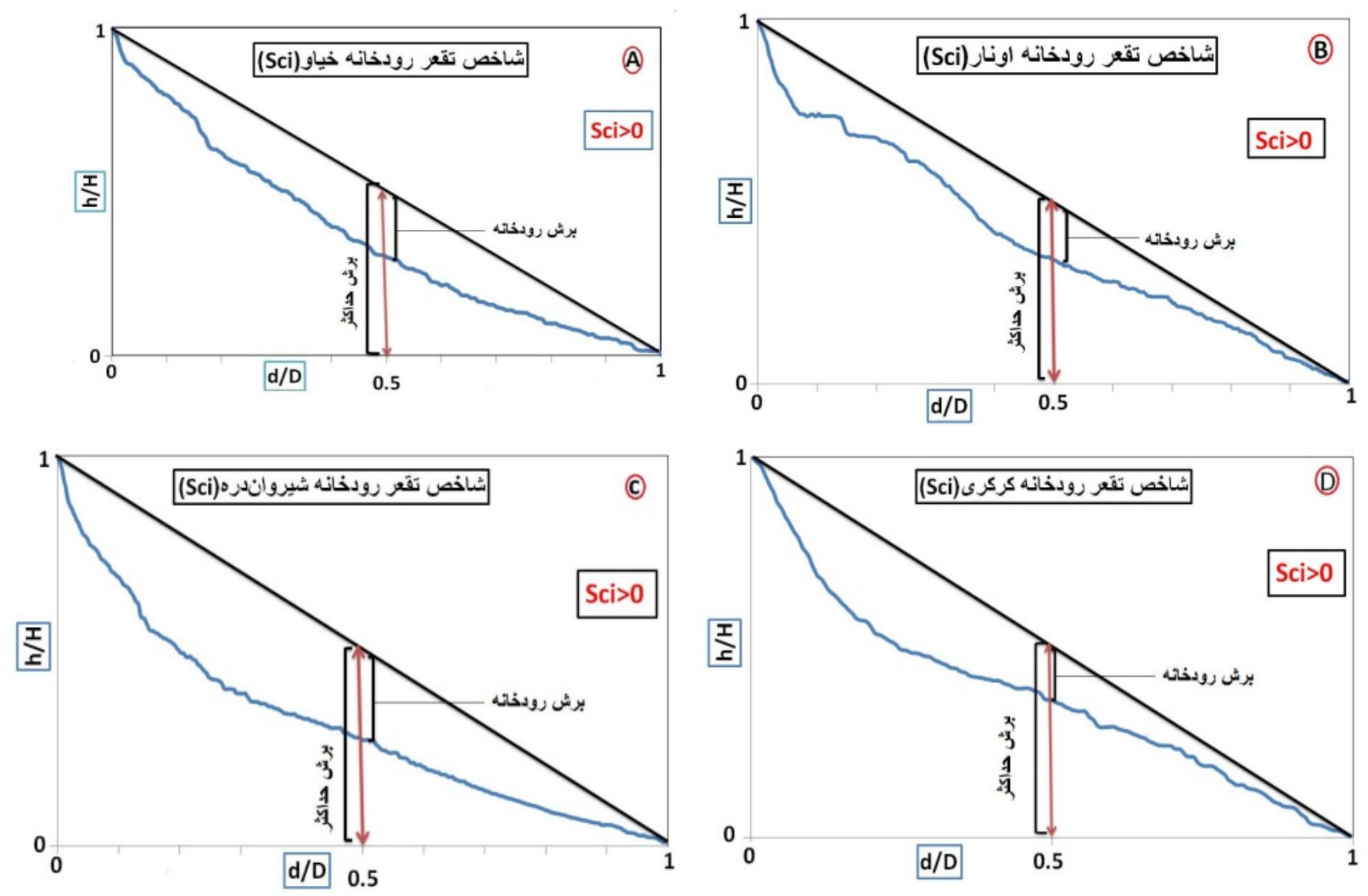

شكل ه) شاخص تقعر رودخانهها، A) خياو B) اونار C) شيروان دره D) كركرى (D)

نمودارهاى ترسيمى (شكل \&)، تروفيل طولى نيمه رودخانههاى

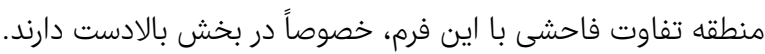

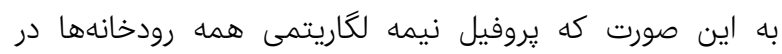

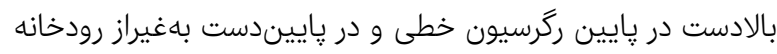

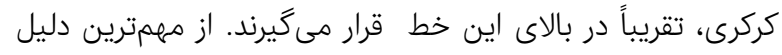

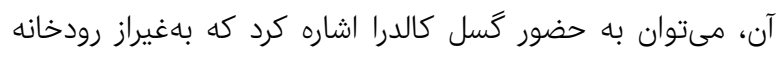

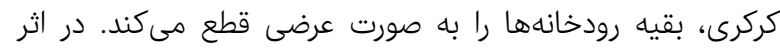

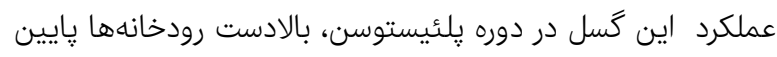

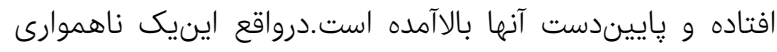

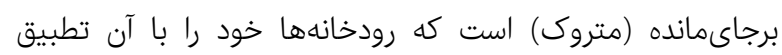

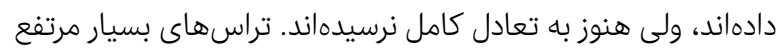

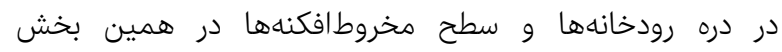

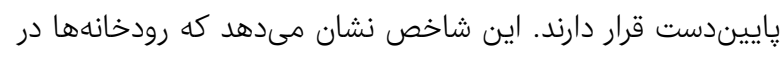

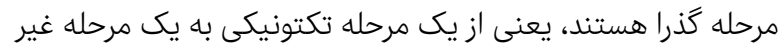

تحليل شاخص نمودار نيمه لكاريتمى رودخانهاى منطقه، جهت رديابى نقش عوامل اقليمى و تكتونيكى: تكامل لندفرمها، نتيجها

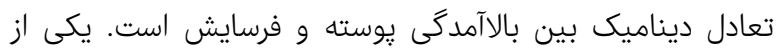

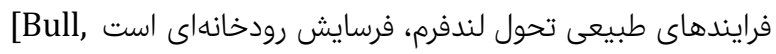
[2008; Burbank \& Anderson, 2001] ديويس نشان مىدهد كه يروفيل طولى رودخانهها در مرحله بلوغ،

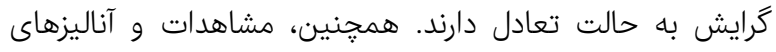
تئوريكى نشان مىدهد كه مدتزمان تحقق اين عمل، حدود (10.

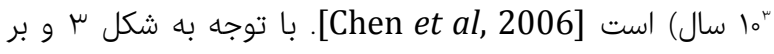
اساس روش جن و همكاران [Chen et al, 2006] به محاسبه و

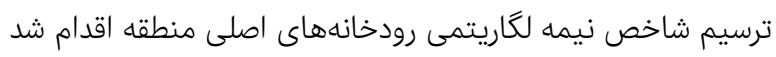

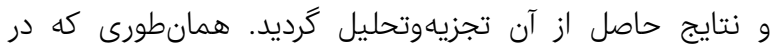

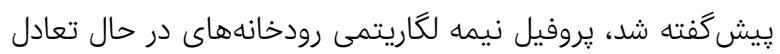

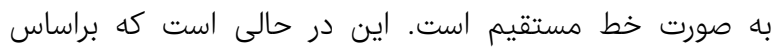


نقش عوامل تكتونيكى و اقليمى دوره كواترنرى در تحول زئومورفولوريك مخروطافكنههاى فرورفتكى مشكينشهر

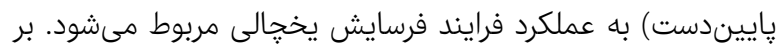

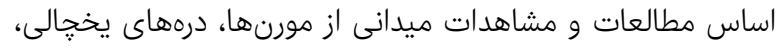

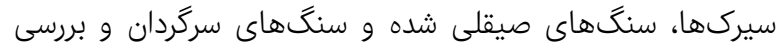

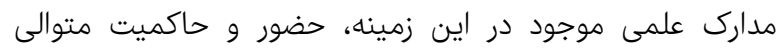

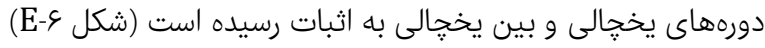
[Dallal oghli, 2003; khayyam, 1993; Rajabi \& Khatibi, 2012]
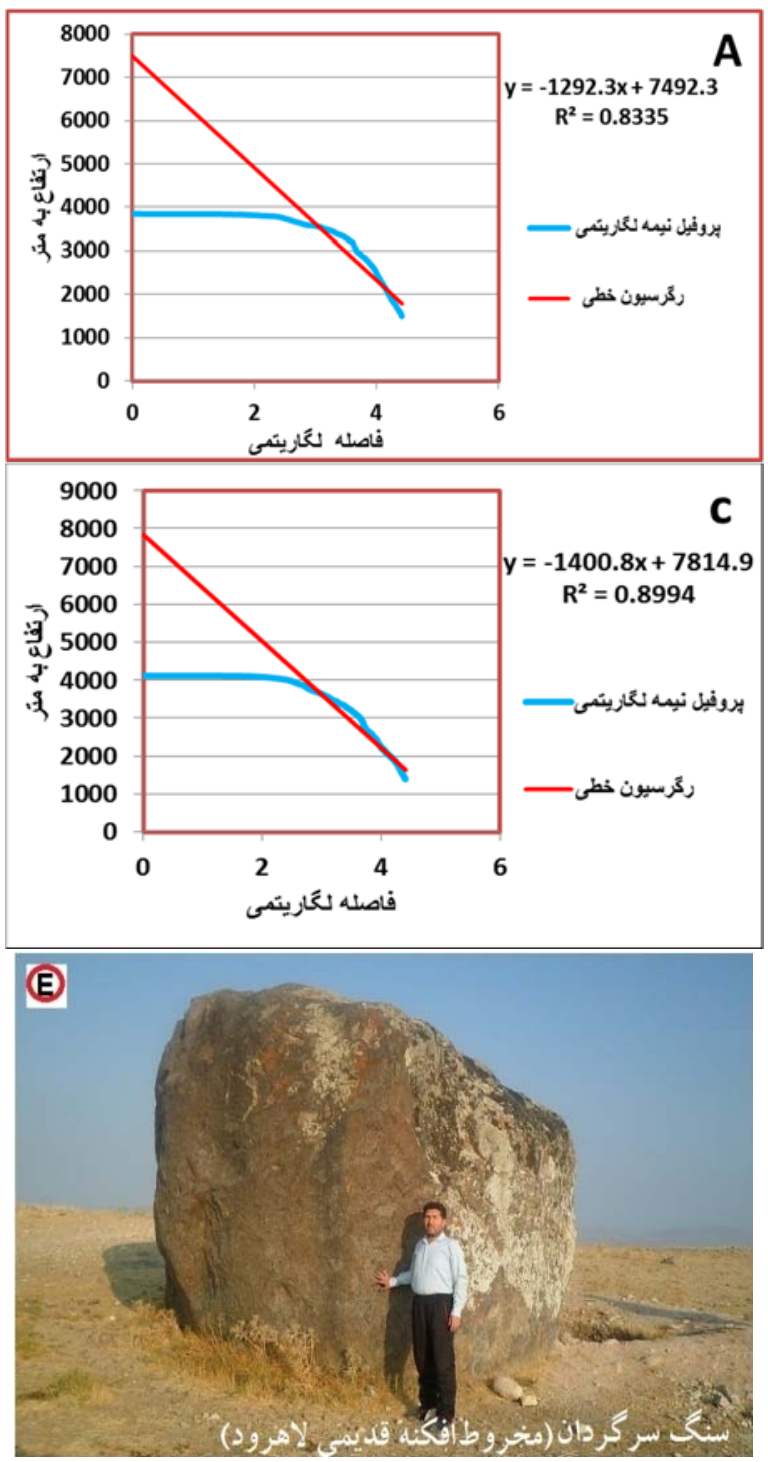

تكتونيكى در حال حركت هستند. در ضمن ضريب k كه نشاندهنده

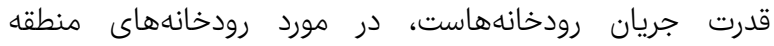

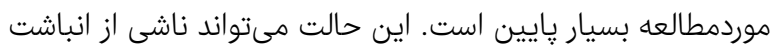

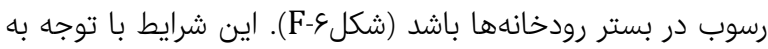

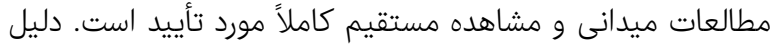

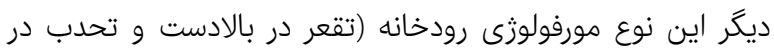
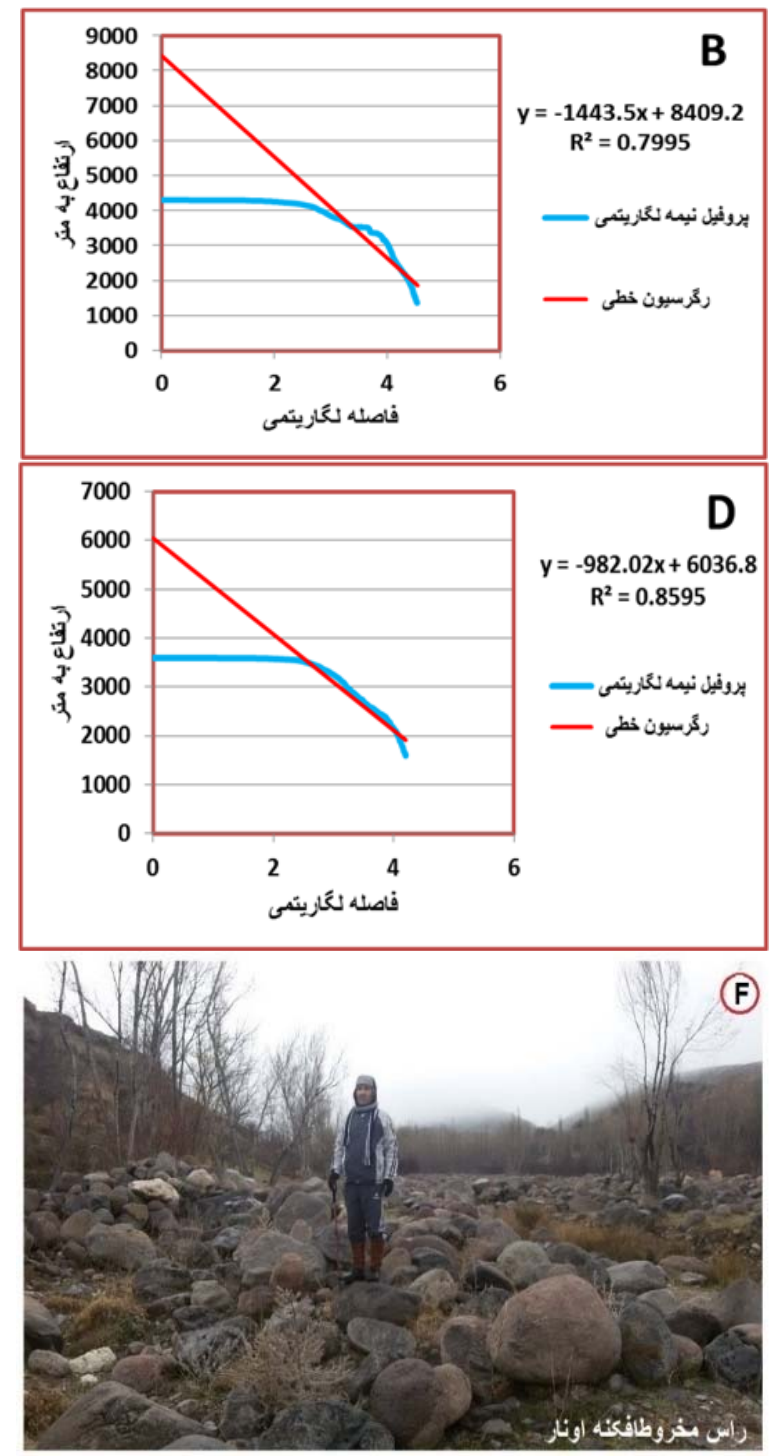

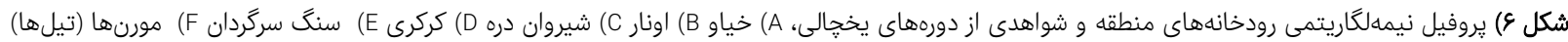

متفاوت تشكيلشده در معرض ديد قرار گيرد. درواقع برش رأس

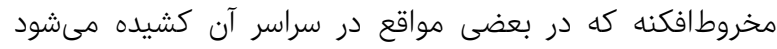

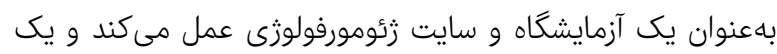

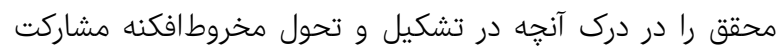

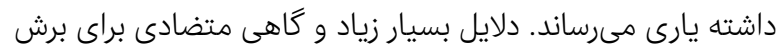

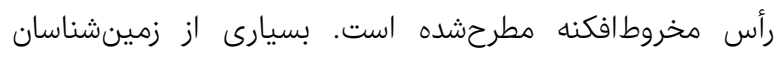

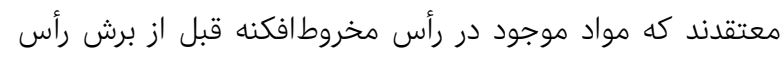

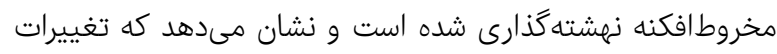

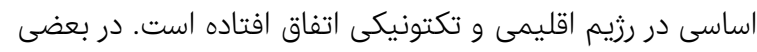

بررسى برش رأس مخروطافكنههاى منطقه جهت رديابى وضعيت

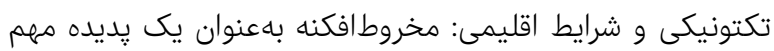

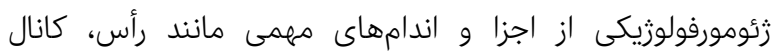
تغذيهكننده، برش رأس، نقطه تقاطع و بيشينه رسوبى فوروفي فعال تشكيلشده است. از بين اين اجزا، برش رأس مخروطافكنه جهت

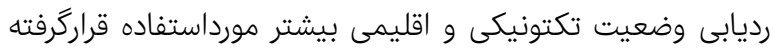

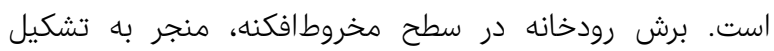

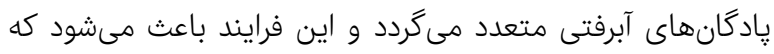
لايههاى درونى مخروطافكنه كه در شرايط تكتونيكى و اقليمى مرى مردى 
ييروكلاستيك ايجاد كرده، مانع حفر جاه در اين مناطق شده است.

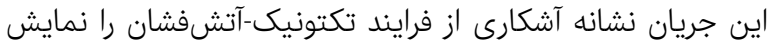

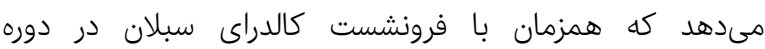
يلئيستوسن اتفاق افتاده است [Mousavi et al, 2011].

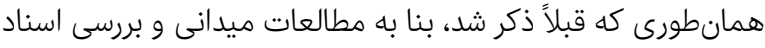
و نوشتههاى ديگران جنين استنباط مىشود كه كوهستان سبلان

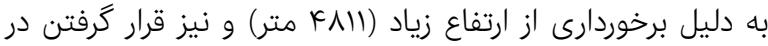

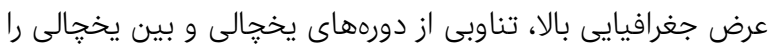

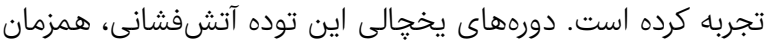

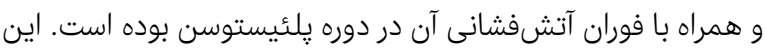

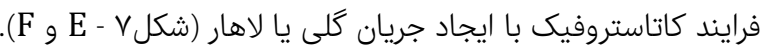

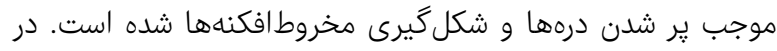

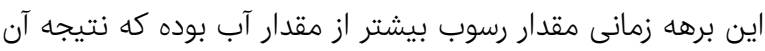
به نهشته شدن فراوردههاى آتشفشانى و يخجالى منجر شده است است.

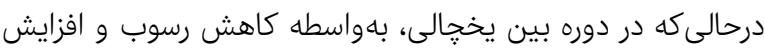
قدرت رودخانهها، برش درهها و رأس مخروطافكنهها باتهان اتفاق افتاده است. براساس مطالعات كتابخانهاى، همه محققين در اين مسيله

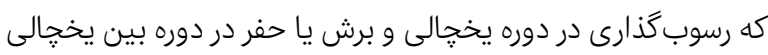

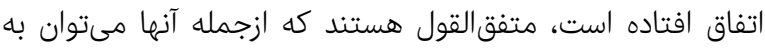

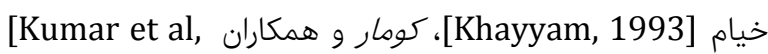
[2007، كويقلى و همكاران [Quigley et al, 2007)، بلير و مكفرسون [Blair \& Mcpherson, 2009] و شريفى نجفآبادى [Sharifi Najaf Abadi, 2019] بررسى نوع و اندازه دانههاى آبرفتى و ضخامت آنها در بخشهاى

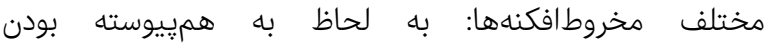

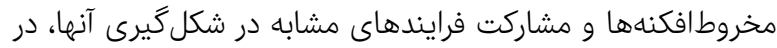
اين بخش به صورت يكيارجه، موردمطالعه واقع مىش مشوند.

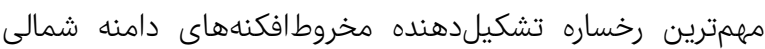

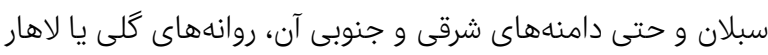

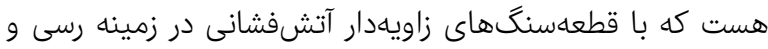

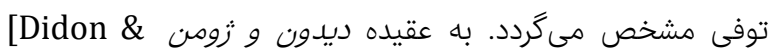

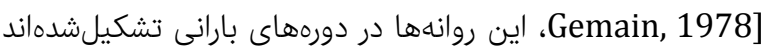
[Khayyam, 1993] [Dall Oghli, 2003] روانههاى مذكور، حاصل آب ذوبان يخجٌالها در مواقع فوران آتشفشان سبلان است. درهرصورت و به هر دليلى كه باشد، اين

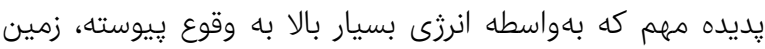

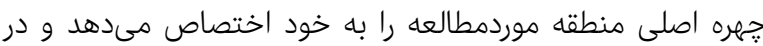

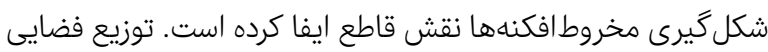
وسيع اين نهشتهها به عقيده خيلى از محققين ناشى از تغييرات

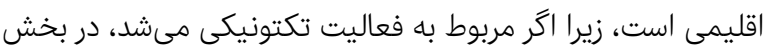

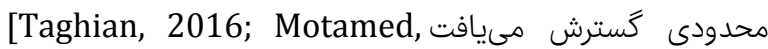

موارد، برش رأس مخروطافكنهانه آنقدر زياد است كه جارى شدن

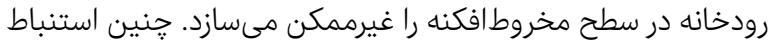

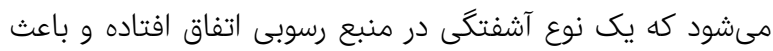

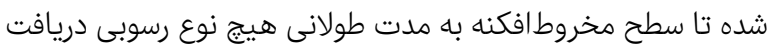

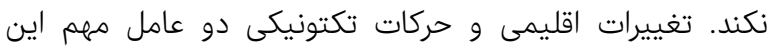

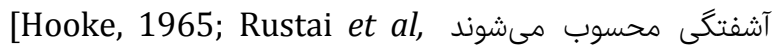

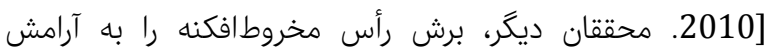
تكتونيكى نسبت مىدهند كه به فرايندهاى فرسايش، فرصت درين انجام

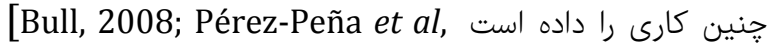
[2010.مشاهدات ميدانى از سطوح و مقاطع مخروط افكنهها و رسم

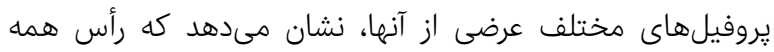

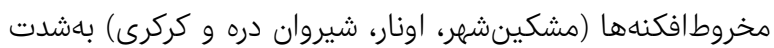

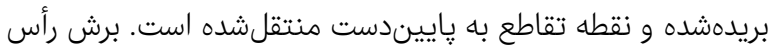

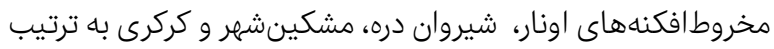

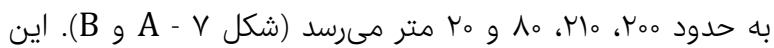

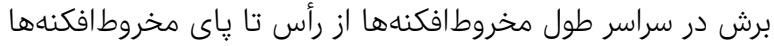

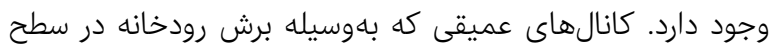

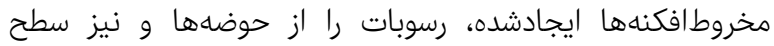

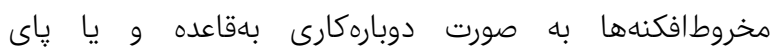

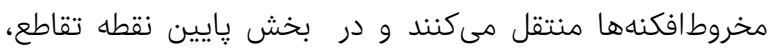
بيشينه رسوبى فعال يا مخروطافكنههاى جديد را به وجود مى آورند.

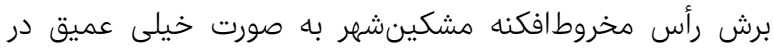
سراسر مخروطافكنه وجود دارد و به اين طريق هيج نوع رسوبى را از از

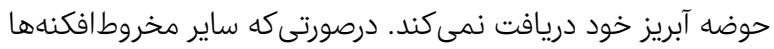
مانند اونار، شيروان دره و كركرى در مواقع طغيانى رسوباتى را از

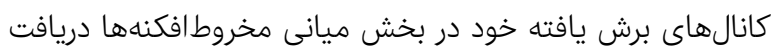

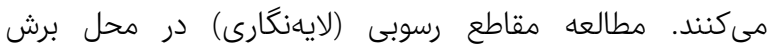

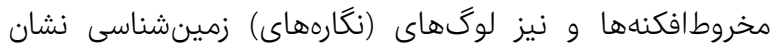
مىدهند كه مخروطافكنهها از تناوب و توالى نهشتههاى بسيار

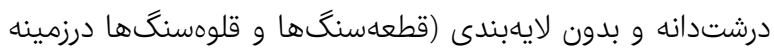
گل) و بسيار ريزدانه و بدون لايهبندى (رس، سيلت، بقداياى كَياهان

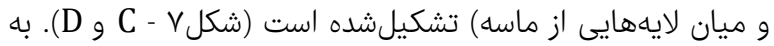

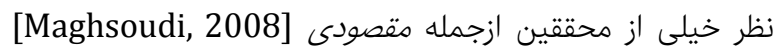

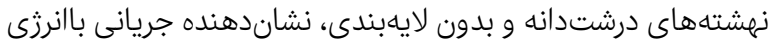

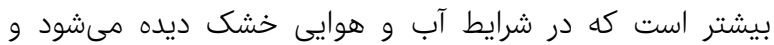

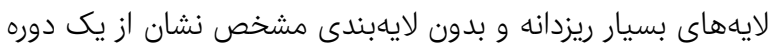

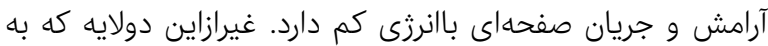
صورت جرخشى در ديواره درههاى رودخانهاى موجود در سطح

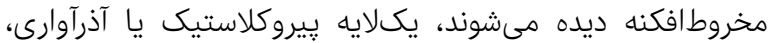

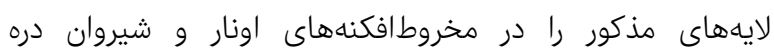

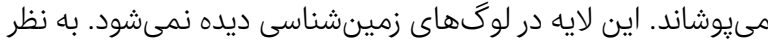

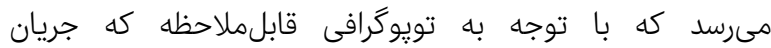



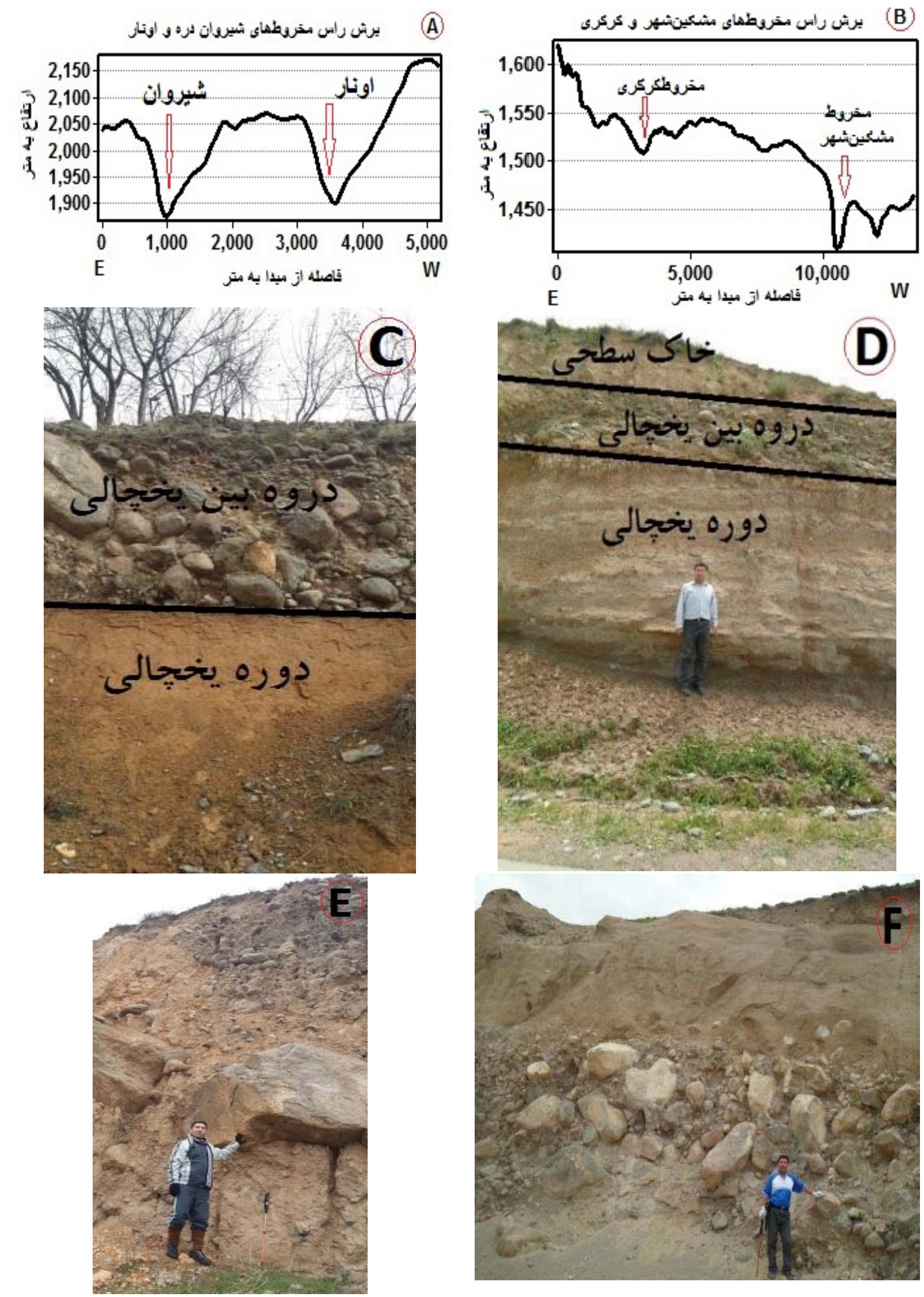

شكل V برش رأس مخروطافكنهاى منطقه مورد مطالعه و مقاطع رسوبى آنها، A) برش شيروان دره و اونار B) برش مشكينشهر و كركرC) ديواره دره اونار D) مخروط

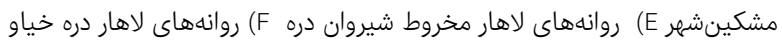



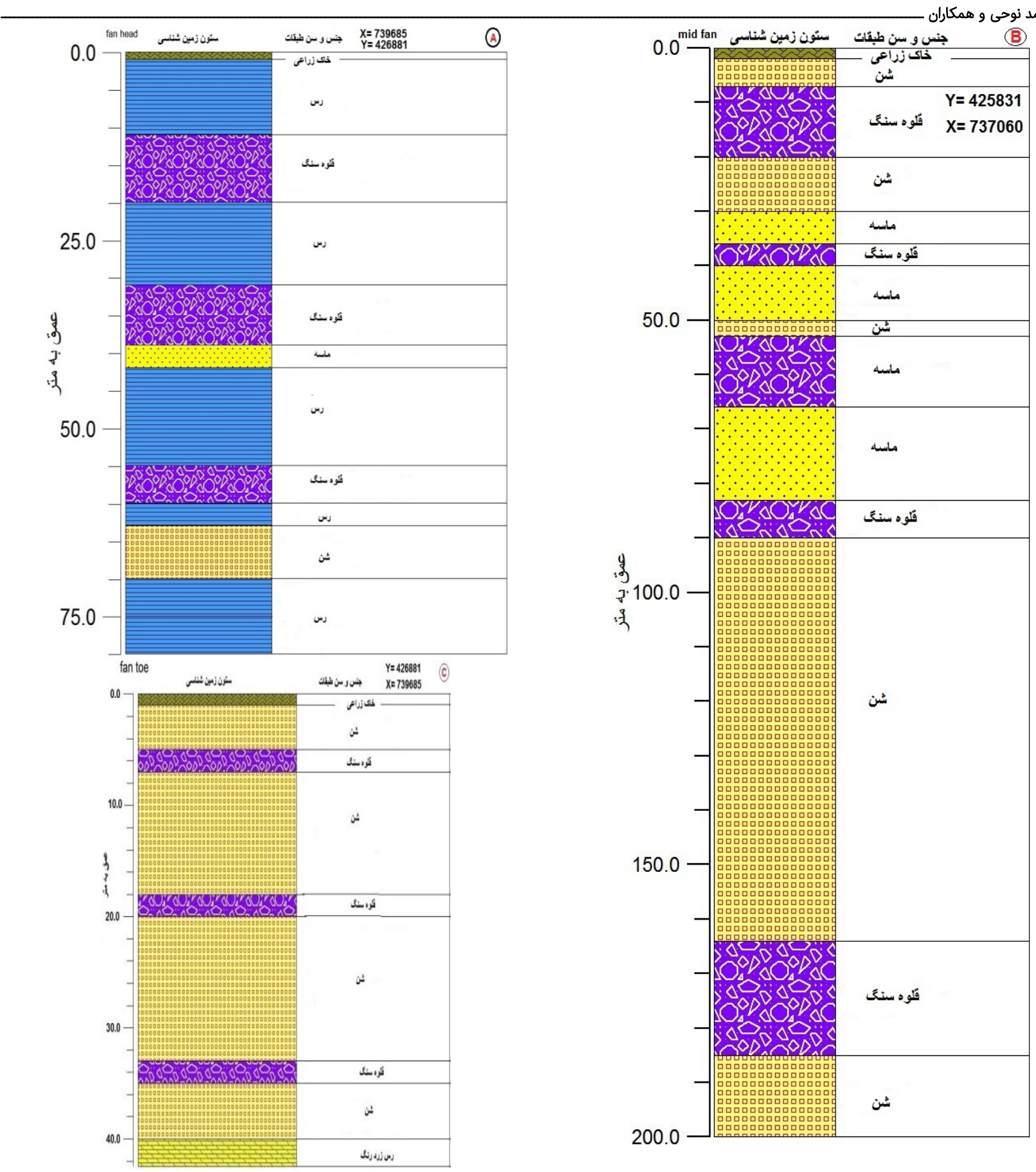

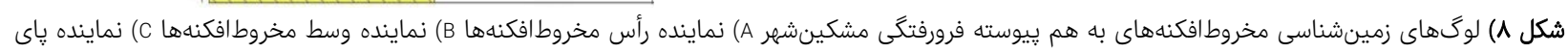

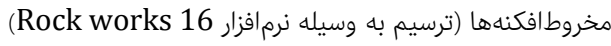

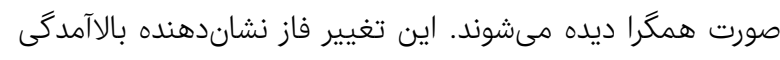

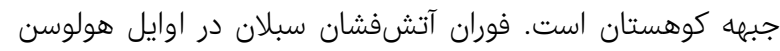

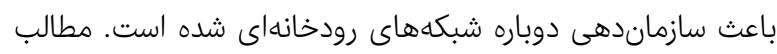
ذكرشده در بالا نشان مىدهد كه در نوع و اندازه دازه دانههاى آبرفتى،

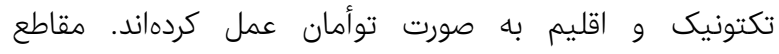

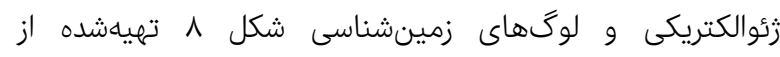

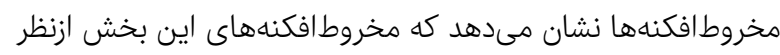

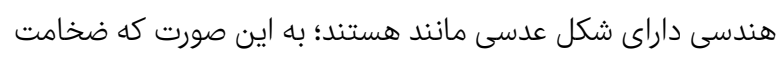

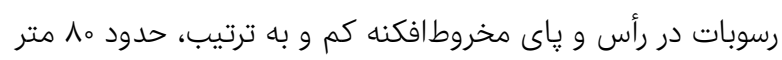

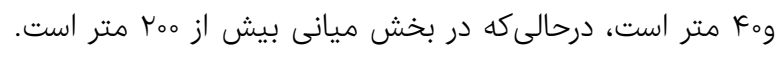
تفسيرى كه ازنظر تكتونيكى، مىتوان براى درآ آن مطرح كرد، آن است
اندازه دانهها و عناصر آبرفتى در سطح مخروطافكنهها از جنوب

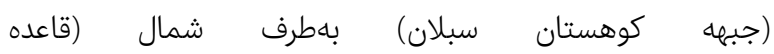

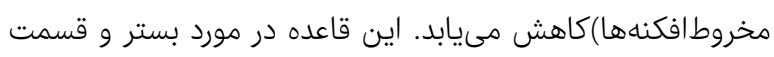

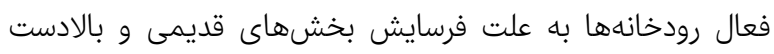

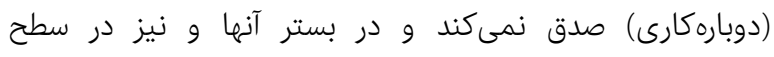

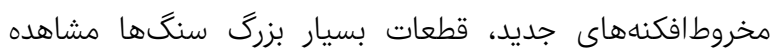

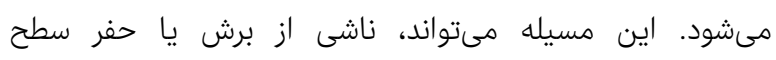

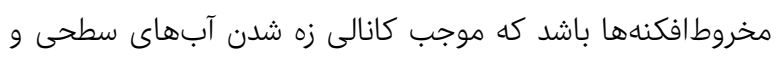

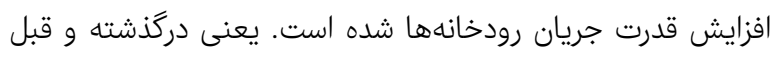

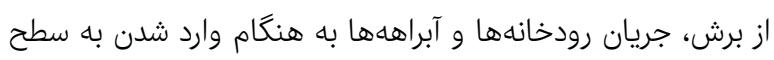
مخروطافكنهها به صورت واگرا و يا گيسويى بودهاند ولى امروزه به بهان 


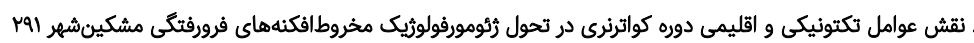

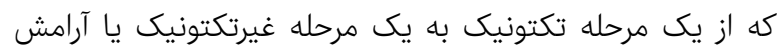

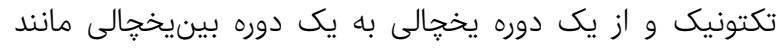

$$
\text { شرايط امروزى رسيده است. }
$$

تشكر و قدردانى: از متصديان مجله وزين تحقيقات جغرافيايى بهويزه

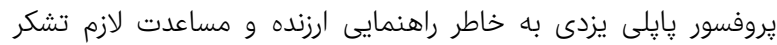

$$
\text { مى تردد. }
$$

تأييديه اخلاقى: موردى از سوى نويسندكان كزارش نشده است.

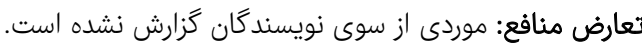

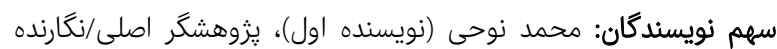

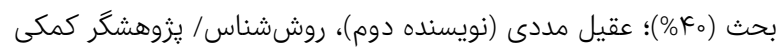

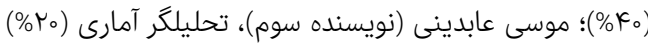

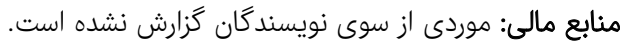

منابع

Blair TC, McPherson JG (2009). Processes and forms of alluvial fans. In: Parsons AJ, Abrahams AD, editors. Geomorphology of desert environments. Dordrecht: Springer. pp. 413-467.

Bull WB (1972). Recognition of alluvial fan deposits in the stratigraphic record. Arizona: SEPM (Society for Sedimentary Geology).

Bull WB (2008). Tectonic geomorphology of mountains: A new approach to Paleoseismology. Hoboken: John Wiley \& Sons.

Bull WB (2011). Tectonically active landscapes. Hoboken: John Wiley \& Sons.

Burbank DW, Anderson RS (2013). Tectonic geomorphology. Environmental and Engineering Geoscience. 19(2):198-200.

Chen YC, Sung Q, Chen CN, Jean IS (2006). Variations in tectonic activities of the central and southwestern Foothills, Taiwan, inferred from river hack profiles. Terrestrial Atmospheric and Oceanic Sciences. 17(3):563. Demoulin A (1998). Testing the tectonic significance of some parameters of longitudinal river profiles: The case of the Ardenne (Belgium, NW Europe). Geomorphology. 24(2-3):189-208.

Harvey AM, Mather AE, Stokes M (2005). Alluvial fans: Geomorphology, sedimentology, dynamics introduction, a review of alluvial-fan research. Geological Society. 251(1):1-7.

Hooke RL (1965). Alluvial fans. [Dissertation]. California: California Institute Technology.

Kumar R, Suresh N, Sangode SJ, Kumaravel V (2007). Evolution of the quaternary alluvial fan system in the Himalayan foreland basin: Implications for tectonic and climatic decoupling. Quaternary International. 159(1):620.

Pérez-Peña JV, Azor A, Azañón JM, Keller EA (2010). Active tectonics in the Sierra Nevada (Betic Cordillera, SE Spain): Insights from geomorphic indexes and drainage pattern analysis. Geomorphology. 119(1-2):74-87.

Quigley MC, Sandiford M, Cupper ML (2007). Distinguishing tectonic from climatic controls on rangefront sedimentation. Basin Research. 19(4):491-505.

Viseras C, Calvache ML, Soria JM, Fernández J (2003). Differential features of alluvial fans controlled by tectonic or eustatic accommodation space, examples from the Betic Cordillera, Spain. Geomorphology. 50(1-3):181-202.
كه در اين منطقه، بالآمدگى تكتونيكى در طول نهشتهگذارى مخروطافكنهها همجنان ادامه داشته است. خيام و مختارى [Khayyam \& Mokhtari, 2004] همين نتيجه رسيدهاند. همجنين با بررسىهاى انجامشده از مقاطع،

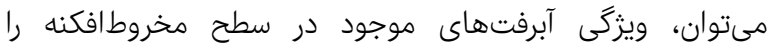

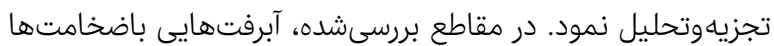

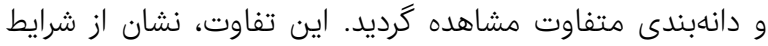

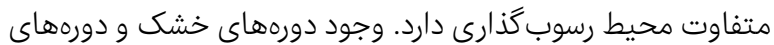

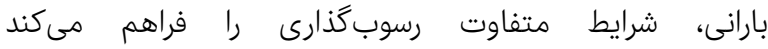

.[Maghsoudi, 2008]

يثزوهش حاضر كه در مورد نقش عوامل تكتونيكى و اقليمى دوره

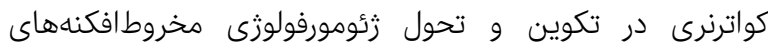

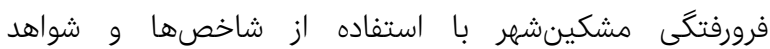

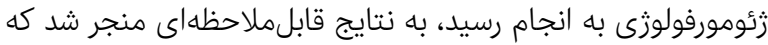

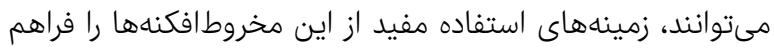

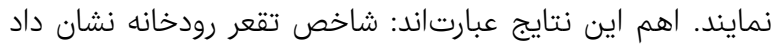

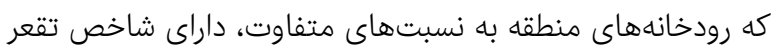

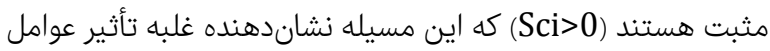
اقليمى بر فعاليت تكتونيكى است. شاخص نمودار نيمه لكَاريتمى رودخانه كه يكى از مهمترين شاخص زئومورفيك در نشان دادن لنان فعاليتهاى تكتونيكى است، نشان داد كه منطقه موردمطالعه ازنظر

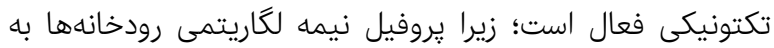
صورت خط مستقيم نيست (عدم تعادل)، بلكه در بالادست داراى تقعر و در קاييندست دارى تحدب است. شاخص برش رأس ريس

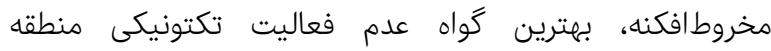
موردمطالعه است. در عوض نقش اقليم با برش و حفر رأس مخروطافكنههاى منطقه نمود يِيدا مىكند. در مناطق با تكتونيك

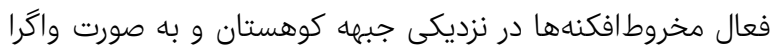
يا گيسويى شكل مى

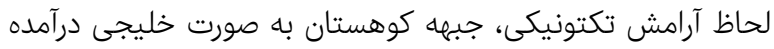

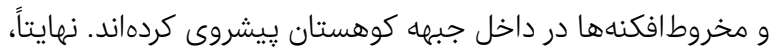

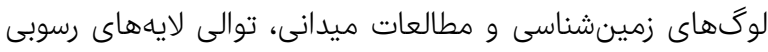

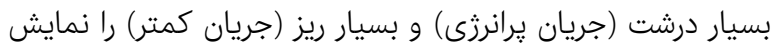

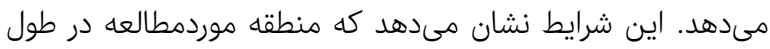

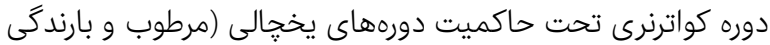
مداوم) و دورههاى بين يخجالى (خشك و طوفان تندرى) قرارگرفته

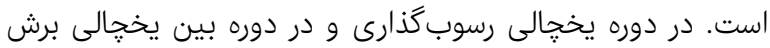

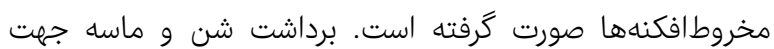
استفاده در كارهاى عمرانى به لحاظ يايين بردن سطح اساس منطقه، تشديدكننده عمل حفر مخروطافكنهها است.

\section{نتيجه نيرى}

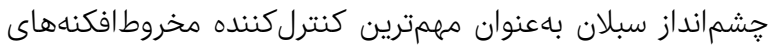
فرورفتگى مشكينشهر در يك مرحله گذار قرار دارد؛ به اين معنى محرونى 
Jajrood fan). Physical Geographic Research. 40(65):73-92. [Persian]

Motamed A (1994). Geography quaternary. 2nd Edition. Tehran: Samt. [Persian]

Mousavi Z, Darvishzadeh A, Ghalamghas J, Abedini MV (2011). Discussion on stratigraphy questions at Sabalan volcano and Sabalan geothermal exploration project, Meshkinshahr, Iran. GRC Transactions. (35):931-934. [Persian]

Rajabi M, Bayati Khatibi M (2012). The geomorphology of northwest Iran. 1st Edition. Tabriz: Tabriz University. [Persian]

Rajabi M, Soleimani A (2013). Analysis and evaluation of the morphotectonic and neotectonic characteristics of the southern slopes of Sabalan mountains. Geography and Planning. 17(45):97-120. [Persian]

Rustai S, Rajabi M, Zomorrodian, MJ, Moghami Moghim G (2009). The role of tectonic activities in the formation and development of alluvial fans in the southern slopes of Ala Dogh. Geography and Development. 7(13):137-156. [Persian]

Sahabi F (1999). Sabalan volcanic complex with special reference to the hydrotermal sources in Meshkinshahr area, NW Iran. Geosciences, Geological Survey of Iran. 8(31-32):1-14. [Persian]

Sharifi Najafabadi R (2019). Glacial and tectonic evidence of late Quaternary in Cheshmeh - Langan basin of Isfahan. Iranian Journal of Geographical Researches. 33(2):223237. [Persian]

Taghian A (2016). Investigating the role of tectonic on the morphology, segmentation and evolution of Moghar fan (north of Ardestan). Geographical Research. 30(1):119134. [Persian]

Yamani M, Maghsoudi M (2003). The role of tectonics and climate change on the development of alluvial fans (case study, alluvial fans of Sirjan graben). Desert. 8(1):151138. [Persian]

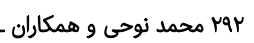

Whittaker AC (2012). How do landscapes record tectonics and climate?. Lithosphere. 4(2):160-164.

Zaprowski BJ, Pazzaglia FJ, Evenson EB (2005). Climatic influences on profile concavity and river incision. Journal of Geophysical Research: Earth Surface. 110(F3).

Amini B (1994). Geological map of Meshkinshahr, Scale, 1 : 100000, Sheet 5566. Geological Survey of Iran. [Persian] Babakhani A, Khanazareh N (1991). Geological map of Lahrood, Scale, 1: 100000, Sheet 5567. Geological Survey of Iran. [Persian]

Dallal Oghli A (2003). The study of the effective morphogenesis systems in the northern slope of Sabalan mountain and the formation of the accumulation plain of Meshkinshahr. Geographical Researches. 35(45):1-12. [Persian]

Darvish Zade A (2007). Volcanology. 4th Edition. Tehran: Payam Noor University. [Persian]

Goorabi A, Karimi M (2012). The effect of active tectonics and climate change on the development of Marvast alluvial fan, central Iran. Applied Geosciences Research. 12(27):7-30. [Persian]

Kamali Z, Heyhat MR, Nazari H, Mehdi Khatib M (2018). Investigation of Drood fault (Southwestern Iran) based on geological and geomorphologic studies of alluvial fans. Geography and Development. 16(53):51-68. [Persian]

Khayyam M (1993). An attempt on the constructional and volcanic morphology of the Azerbaijani plateau with emphasis on Sabalan volcanic mass. Journal of Faculty of Literature and Humanities, Tabriz University. 36(146147):32-50. [Persian]

Khayyam M, Mokhtari D (2003). Evaluation of the role of tectonic activities based on the alluvial fans morphology (case study: Alluvial fans of the northern Misho-Dagh's). Geographical Research. 35(1):1-10. [Persian]

Maghsoudi M (2008). Investigating the factors affecting the development of the fans geomorphology (case study: 